\title{
DOCUMENTACION
}

\section{Respuesta de Leonardo Boff a la carta del cardenal Joseph Ratzinger, prefecto de la congregación "para la doctrina de la fe, sobre el libro "Iglesia: Carisma y Poder."}

L.a revisı // regno, quindicinale di attialita e documenti, Bologna, publicí c'n su número 514, (1984) la carla del cardenal Ralzinger del 15 de mayo de 1984 a L. Boff sobre su libro Islesia: carisma y poder, y la respuesıa de L. Boff a dicha carta del 24 de agosio de 1984.

Se reproduce a continuación una Iraducción de la respuesta de $\mathrm{L}$. Borr, en los punıos leológicamente más perlinentes. No se publica la carta del Cardenal Ralzinger porque la respuesta de L. Bofl la cila en sus párrafos más importanles.

I_as páginas ciladas del libro /glesia: carisma y poder, tanto en la carta del cardenal como en la respuesia de L. Borf, corresponden a la versión original porluguesa, Egreja: carisma e poder, Petrópolis, 1981.

I11. Respuestas a las observaciones de carácter general y metodológico

\section{Doctrina de la Iglesia y magisterio}

Dice el rexio de la carta del cardenal Ratzinger:

En el intento de acercarse a los problemas de América Latina y, en particular de Brasil, no se presta atención a la docırina de la Iglesia y del magisterio con un estudio directo y profundo y se acude a una cierta corriente teológica desgraciadamente discutible y más propia de otros conlexlos (Hasenhütl, Carisma, Ordnungsprinzip der Kirche, Hans Küng; Ernst Kasemann, elc.). 
El magisterio es cierramente un lugar teológico, pero no es el único ni si quicra el más imporiante. la sana teología se construye como una mesa sobre cuatro patas: la Escritura, la tradición, el magisterio y la razón teológica. A pesar de la disparidad de los Irece articulos que componen Iglesia: carisma y poder (sus deslinalarios van desde CEBS hasla los obispos), hay en las citas que hago un nolable predominio de la Sagrada Escritura, "alma de la Sagrada Teologia' (Dei Verbum, 24).

Cito 228 textos escriturísticos; hablo (sin citar los textos) 120 veces del evangelio; 20 de la Sagrada Escrilura, 45 clel Anliguo y Nuevo Testamento; de donde se deduce la importancia capital de la referencia biblica con 413 referencias.

Los dos últimos capítulos sobre el carácter pneumático de la Iglesia están prácticamente elaborados a base de referencias biblicas sobre textos relativos al tema.

Además hay una presencia significativa de los Santos Padres. Los cito 49 veces, preferentemente a San Agustín (13 veces) y a continuación otros como lgnatiu de Antiocjuia, I.con Magno, Clementc Romano, etc.

Pero vayamos al magisterio; de hecho este es el punto doliente de las observaciones del cardenal: 52 veces cilo a los papas recientes, teniendo en cuenta que más de la mitad (7) de los estudios se publicaron antes de la elección de Juan Pablo II,79 veces cito el Vaticano $11 ; 78$ veces Puebla; 56 me remito al magisterio sin especificar los textos, en sentido positivo. Inumerables las citas de la conferencia nacional de los obispos.

El capitulo Ill ("La Iglesia y la lucha por la justicia y el derecho de los pobres," 42-57) ha sido lotalmente elaborado sobre documentos oficiales del magisterio como la Octogesima Adveniens, la Evangelii Nuntiandi, la $R e$ dempror Hominis, la Justicia en el mundo, la Lumen Gentium, la Evangelica Tesifficatio, el documento de Puebla, y los documentos de la CNBB. Creo al menos que en este capitulo se de "un estudio directo y profundo" del magisterio y de la sana doctrina de la Iglesia.

Como ya he notado en la introducción, sigo el método que usan habitualmente nuesiras conferencias episcopales, el documento de Puebla y los teólogos: se parte de los problemas de la vida de la Iglesia; se acude luego a la luz de la exégesis, la historia de la Iglesia, el magisırio y la buena literalura teológica, accesible al que hace teologia en un pais pobre como Brasil.

Si se analizan las citas de autores, no es justo afirmat como hace el cardenal Ratzinger que yo prefiero una cierta corriente teológica desgraciadamente discutible. Pongo a pie de páginas 402 citas; y alli están presentes las más diversas corrientes del presente y del pasado: padres de la Iglesia, teólogos medievales, neoescolásticos, representantes de la teologia moderna como Congar, de Lubac, Rahner y J. Ratzinger, como también teólogos latinoamericanos.

Se citan en prueba de mi tendenciosidad los nombres de Hasenhüttl, Küng y Käsemann. Analicemos sin ira ni excesivas sutilezas lo que cito de ellos. 
Ante todo es preciso corregir dos errores de transcripción; Hasenhülll se escribe con dos $t$; el título correcto de su libro es Charisma y no Carisma. Es católico y profesor ordinario de dogmática de la Universidad de Saarbrücken. Estudió en Tübingen cuando J. Ratzinger era alli profesor de la misma materia.

El libro: Charisma. Ordnungsprinzip der Kirche (Herder, Freiburg-BaselWien 1969) es un estudio histórico-dogmático del carisma como principio de organización de la vida de la comunidad. El mismo J. Ralzinger siguió cierlamente la elaboración del libro, pues el autor le muestra su agradecimiento en el prólogo por "sus numerosas y emriquecedoras sugerencias" (fiir ihre - junco con P. Stockmeier - zalhreichen weiterführenden Raischläge.).

El libro tuvo que ser considerado bueno, porque ha sido incluido en la colección dirigida por J. Ralzinger y $\mathrm{H}$. Küng - Okumenische Forschungenpor la editorial Herder (Ekklesiologische Ableilung, Band V: Charisma). Un libro importante para todos los que pretendan escribir sobre un lema lan actual como el de los carismas. Y tambièn es importante para nuestro contexto social -contrariamente a lo que dice la carta del cardenal "propio de otros contextos" - pues los retos sociales y pastorales que descubre la conciencia cristiana nos llaman a la creatividad no sólo para poder dilatar, sino tambièn para mantener la actual situación de la Iglesia.

Gotthold Hasenhüttl demuestra en su libro que la Ordnung (orden, organización) no es en la lglesia una organización juridica externa, sino un principio que hace de la Iglesia un organismo (organicam ut aiunt, como escribia Pio XII). El autor no ignora los ministros instituidos (carismas permanentes) y hace ver la importancia de los carismas personales y comunitarios para la construcción viva y concreta de la Iglesia. Estas perspeclivas me parecen relevantes para nuestra situación de Iglesia que nace de la le del pueblo en la base, como afirmo en los dos últimos capítulos del libro Iglesia: carisma y poder, donde cito expresamente a Hasenhüttl, unas ocho veces.

Cito aqui en total siete veces a Küng. Resultaría exıraño publicar un libro sobre temas eclesiológicos, como el mio, desconociendo la obra fundamental de la eclesiologia pstconciliar La chiesa de Hans Kung. El mismo J. Ratzinger en su libro Das neue Volk Gottes, Düsseldorf, 1969, cita a Küng más veces que yo, en total once veces. En las siete veces que cito aqui lo hago incluyendo dos artículos: "La estructura carismática de la lglesia"' (Concilium, n. 1, 1965, 31 45), y el que trata del problema que yo afronto sobre qué es el catolicismo ("Der Frühkatolizismus im Neuem Testament als kontroverstheologisches Problem," en E. Kuseman, Das neue Testament als Kanon, Götlingen 1970). Como se puede ver no cito ninguna obra de Küng incluida en las condenas de la Congregación para la Doctrina de la Fe, excepto una entrevista en HerderKorrespondenz $(27,1973)$.

Cito seis veces a Kasemann tanto en la colección organizada por él con otros autores, Das neue Testament als Kanon (op. cit.) como en su coleccion de artículos en el Exegetische Versuche und Besinmungen, Bd. 1, Götingen, 1960. La calegoria exegética de Kasemann es tan universalmente reconocida 
que me parece ridiculo que un leólogo, pequeño y periférico como yo, pueda relorcarle alguna cosa.

Concluyendo ya esta parte, pienso que he dado al magisterio el lugar que le corresponde en el discurso global de la teología, sobre todo si se tiene en cuenta la variedad de temas discutidos en el libro, Iglesia: Carisma y poder. En una teologia que tiende a identificar la Iglesia con la jerarquia se corre el riesgo de debilitar la doctrina del magisterio en detrimento de los otros lugares teológicos.

Los pronunciamientos del magisterio son claramente importantes y pueden incluso ser normativos. Pero, como decian los maesiros de la Gregoriana, Z. Alszeghi y M. Flik," por sí solos estos pronunciamientos no bastan para iniciar el trabajo teológico y aún menos constituyen el fundamento úlıimo. Las fórmulas del magisterio no son una pista de despegue adecuada para la investigación teológica... Las fórmulas propuestas con autoridad surgen generalmente de determinadas situaciones históricas, concentrando la atención sobre aspectos polémicos e inevitablemente unilaterales" (Como se faz reologia. Sao Paulo, 1979, p. 41).

\section{El lenguaje}

Reza asi el segundo punı de la carta del cardenal Ratzinger:

La segunda observación general se refiere al lenguaje usado. Falta a veces, la necesaria serenidad y moderación, fruto de la caridad, la justicia y el respeto hacia las personas e instituciones de la Iglesia. Por el contrario, su tono es polémico, difamatorio, e incluso panfletario, absolutamente impropio de un teólogo (c「 pp. 65 y ss; 89 ss; 238-240). Además falta más con frecuencia todavía la precisión teológica: los tèrminos usados adquieren un significado ambiguo, por ejemplo cuando se habla de "sincretismo" (cf pp. $145 \mathrm{ss}$ ). Quien desea edificar la Iglesia y consolidar su comunión interna debe utilizar un lenguaje sereno y moderado y, al mismo liempo, tambièn más coherente con el uso propio del magisterio.

Aquí se critican dos faltas: una de moderación con el lenguaje y la olra de precisión del lenguaje teológico. Afrontemos por separado las dos cuestiones.

\section{a) Falta de moderación del lenguaje y tradición profética}

El lenguaje depende del género literario utilizado; los géneros por su parte dependen de los problemas discutidos como ya observaba Aristóteles. La teología conoce los distintos lenguajes, y nosotros teólogos (también yo) usamos ayer y hoy distintos géneros literarios.

Existe el lenguaje narrativo, el reflexivo, el cientílico-técnico, el pastoral y también el profético. El teoblogo, según las circunstancias, puede hacerse pastor (como la mayoría de los antiguos, que eran obispos y teólogos), poela (santo Tomás), místico (san Buenaventura) y profeta (san Juan Crisóstomo y san Antonio de Lisboa).

En mi libro critico situaciones deplorables en la lglesia de ayer y de hoy. 
Ante Iodo es preciso aceplar la realidad: existen pecadores en la lglesia. No pretendo entrar en la discusión de cómo ha de entenderse esta realidad negativa de la comunidad cristiana: si existe una Iglesia pecadora o si es santa, aunque esté formada por pecadores (teorías de C. Journet, Y. Congar, K. Ranher, H. Urs von Balthasar y otros).

Sólo quiero recordar que existe una larga tradición teológica que se refiere a la Iglesia como a una casta meretriz, objeto de un estudio erudio de Von Balthasar (Sponsa Verbi, Einsiedeln 2/1971, 203-305). El habitus meretricius de la Iglesia fue lan duramente criticado por los padres como Ambrosio, Agustín, Jerónimo, Bernardo y por teólogos como el gran obispo Wilhelm von Auvergne que mis expresiones parecen incluso demasiado moderadas. Yo nunca he llegado a pronunciar frases como las de san Pedro Damiani que llama al Papa Gregorio VII "San Satanás" (cᄃ. D. Romag, Compendio de Historia da Igreja, vol 11, Petrópolis 1950 , p. 112). H. Riedlinger ha recogido muchísimos rexıos en este senıido (cr. Die Makellosigkeil der Kirche in den lateinischen Hohewiliedskommentaren des Mittelalters, Münster, 1958).

En las páginas citadas critico el autoritarismo que persiste en ciertas personas situadas en el poder dentro de la Iglesia, la escasa libertad de información y expresión en algunos sectores de la misma, algunos procedimientos de la Sagrada Congregación para la Doctrina de la Fe en su legítimo oficio de promover y defender la fe del pueblo de Dios. Si tuviera en cuenta la creciente conciencia de los derechos humanos y del sentido juridico de los hombres de hoy, la Congregación podria perleccionar, tambièn conmigo, sus formas de proceder. Lo digo con sinceridad y humildad porque no me han gustado las criticas que vienen de hermanos en la fe y de amigos de ruta que, aun no siendo cristianos, admiran el compromiso de la Iglesia y del Papa en pro de la justicia en el mundo.

Critico duramente el culto a la personalidad que algunos sectores de la Iglesia alimentan hacia las autoridades eclesiásticas, hasta el punto de que un autor reciente escribe este evidente error teológico: "de hecho, el Papa es Dios sobre la tierra... Jesús ha colocado al Papa al mismo nivel que Dios"' (Iglesia: carisına y poder, 89-90).

Ante situaciones semejante la teologia tiene que convertirse en profecía, denunciar y anunciar. He utilizado este género en los casos referidos, aunque no me considero un profela sino un escriba (que liene que escuchar siempre las críticas de Jesús contra los escribas). Es evidente que este género no se expresa con un lenguaje "sereno y moderado;" es denuncia y, por su misma naturaleza, es polémico.

¡Ojalá nos sirvan de ejemplo en esıe campo los profelas que, según Max Weber, fueron los primeros provocadores de la historia! lsaías llama prostituta a uno de los símbolos más significativo del Antiguo Testamento, Jerusalén, porque se habia vuelto infiel a Dios. Lo mismo hará Ezequiel al pronunciar estas crudas palabras: "los amantes de Jerusalén tienen miembros sexuales de jumento y su orgasmo es como el de los sementales en celo" (Ez. 23,217). Amós llama "vacas de Basán" $(5,1)$ a las nobles señoras de Samaria. Podria multipli- 
car estos ejemplos sacados de las distintas tradiciones del Antiguo Testamento.

El profeta Jesís de Nazaret usó palabras duras con los fariseos; les llamó sepulcros blanqueados, serpientes, raza de víboras, homicidas, hijos de prostitución y del diablo (cf. Mi. 23,13-38; Jn. 8,42-44). Llamó demonio a Judas (Jn. 6,70). A Pedro le llamó piedra por su prolesión de fe, y "satanás" por su poca fe (Mt, 16,23). Pablo en un momento de furia contra los gálatas, exclama: "ojalá se castrasen todos aquellos que os turban"' (Gl. 5,12).

Ciertamente no consideramos "difamadoras e incluso violentas, absolutamente impropias" semejantes expresiones venidas de autores inspirados, profetas, el mismo Hijo de Dios y sus apóstoles; asi pues tenemos que entender y tolerar expresiones salidas de un pequeño teólogo pecador, que jamás dejó de amar a la Iglesia, la cual, a pesar de sus arrugas y negligencias, no deja de ser mi madre en la fe.

En cuanto a la tradición replógica me detendré apenas en un cohermano medieval el dulce y profético san Antonio de Lisboa (1195-1231). En sus sermones usa una vigorosa critica religiosa a la religión y a las costumbres de los prelados de su tiempo. Tomemos solo algunos textos.

Los centinelas de la Iglesia (los obispos) son "perros sin ninguna vergüen$\mathrm{za}$, porque su rostro se ha vuelto rostro de meretriz y por esto no quieren tener vergüenza" (sunı canes, inpudentissimi, quia frons meretricis facta est eis; et ideo nolunt eruvescere); "este es su camino tenebroso y lúbrico desde el primero al último, desde el señor cerdo a cerdito" (haec est via illorum tenebrosa et lubrica a summo usque ad novissimum, a domino porco usque ad porcellum. S. Antononii Patavini, Sermones dominicales et in solemnitatibus, 2 vol. I, Padova, 1895, cuarto domingo después de pentecostés, p. 278).

Oira vez. llama a los prelados "monos sobre el tejado que presiden el pueblo de Dios" (simia in recio praesidentes Dei populo; domingo noveno de pentecostés, $o p$. cit., 348). Y continúa: “el prelado de la Iglesia es un esclavo que pretende reinar, un principe inicuo, un león rugiente, un oso hambriento de rapiña que despoja al pobre pueblo" (op. cit., 348). En otra ocasión dijo con énfasis: "el verdadero José es Jesucristo vendido por los negociantes, los arzobispos, los obispos y muchos prelados de la Iglesia. Corren y recorren, compran y venden la verdad con mentiras y aplastan la justicia con simonia. Son comerciantes los abades, los priores hipócritas y los falsos religiosos que venden en la plaza de la vanidad humana mercancias falsas de sucia santidad bajo pretexto de religion, por sed de dinero y gloria humana" (décimo domingo de pentecostés, op. cit., 392): Finalmente en la fiesta de san Pedro levanta su voz y grita: "vea cómo Cristo dijo tres veces: apacienta, y ninguna dijo esquila y dispón... Ay de aquel que nunca apacienta, pero trasquila y dispone tres o más veces... El pastor que abandona el rebaño que le ha sido encomendado es un idolo en la Iglesia, porque es un dragón junto al arca del Señor, que tiene las apariencias y no la verdad. ¿Para qué puede interesar este ídolo marchito a la Iglesia de Cristo?" (op. cit., vol. II, 918).

Estamos seguros de que san Antonio no quiere difamar a las persones y a 
las instituciones de la lglesia. Es el predicador de la Iglesia declaradu doclor, qui se convierte en profeta y utiliza el género propio de los profetas. Estos no son cómodos para nadie y menos para las instituciones por más sacrosantas que sean.

Existe un lugar para la profecía dentro de la lglesia cspecialmenle frente a los abusos que escandalizan a los pobres y desacreditan el mensaje de Jesuis. Los hechos que narro en mi libro (pp. 65 y 238-240) pueden probarse, no son proyecciones de una fantasia delractora.

Decía con razón en su tiempo el teólogo alemán J. Ratzinger: "el sentido de la profecía reside, en realidad menos en algunas predicciones que en la protesta profética: la protesta contra la autosatis「acción de las instituciones, que sustituye la moral con el rito y la conversión con las ceremonias" " "Freimut und Gehorsam," en Das neue Volk Gorles, op. cir., 250-25I). En el sermón del diácono Esteban en los Hechos de los Apóstoles (7, 1-53), continúa Ratzinger, "se demuestra que Dios más allá de la historia, eslaba no al lado de las institu. ciones, sino de parte de los que sufren y son perseguidos... Jesús es la plenitud de los profetas no porque en El se realicen algunas previsiones, sino especialmente porque vivió y sufrió hasta lo más hondo la linea profética del Espiritu, la linea de la no autoexaltación de las instituciones sacerdotales" (op. cit., 251).

Ratzinger critica enfáticamente la separación puritana que hemos hecho en la persona de Pedro: antes de la pascua era el traidor; después de pentecostés, el fiel. Pedro continúa viviendo esıa tensión del principio y el después; continúa siendo ambas cosas: la piedra y el escándalo, el hombre que profesa la fe cristiana ( $\mathrm{J}$ n. 6,68 s.) y el que por miedo de los judios niega la libertad cristiana (GI. 2,1 ss.). Se pregunta el teólogo, hoy cardenal: “ ¿ no ha ocurrido acaso en la historia de la Iglesia que el Papa fuera al mismo tiempo el sucesor de Pedro, "piedra" y "escándalo," piedra de Dios y piedra de escándalo?" (op. cit., 259).

Queda con todo claro que, si por un lado comparamos a la Iglesia con Jerusalén y Babilonia, donde residen contemporáneamente Cristo y el Anticristo, no renunciamos jamás a la verdad del credo que nos invita a reconocer a la Iglesia santa con la santidad de Jesucristo y de su Espíritu, de todos sus santos y santas, de sus sacramentos y su magisterio solemne e infalible.

Pensamos con santo Tomás que la Iglesia "sólo en la paıria celestial está sin mancha ni arruga, no ahora que está todavia en camino; de lo contrario nos engañamos a nosotros mismos con la ilusión de no tener pecado" (1 Jn. 1,8: S. theol. 3 q.8, a.3. ad 2).

Siempre he procurado salvar esta perspectiva: yo critico las situaciones que se dan en la Iglesia. Cuando hablo de las violaciones de los derechos humanos como problema interno de la Iglesia, afirmo claramente: "nuestra intención no es denigrar a la Iglesia dentro de la que nos situamos con un trabajo que supone por el contrario una adhesión explicita a su valor sacramental... Su credibilidad cuando proclama los derechos humanos y denuncia sus violaciones depende del respeto que la misma Iglesia practique en su interior" (Igle- 
sia: carisma y poder). En olro parágrafo afirmo: "digo que sólo un amor concreto y evangélico y por eso mismo critico y libre puede aceptar a la Iglesia con sus límites y errores porque solo amándola nosotros nos convertimos y empieza a manifestarse la fascinación de la esposa de Cristo y madre de todos los hombres" (OP. cir., 101).

Con esto pienso haber demostrado que mi lenguaje no es desacostumbrado; en su género, se sitúa dentro de una larga tradición reológica que se alegraba por el brillo de la santidad de la Iglesia; sin triunfalismos y con capacidad crítica para señalar las sombras y los pecados que una vez. reconocidos, obtienen el perdón de Dios, el teólogo, como la mayor parte de los cristianos, ejerce la profecia dentro de la comunidad que ama tal cual es, negra y resplandeciente.

b) La "falla de precisión del lenguaje" y lo inadecuado de cualquier razo. namiento sobre la reralad divina

El segundo punto en litigio seria la falta de precisión teológica; como ejemplo se cita la ambigüedad de la expresión "sincretismo."

Ante todo admito que falta precisión teológica en toda mi producción; no por mala voluntad, sino por la inadecuación estatuaria (Congar) de cualquier formulación humana (incluso las inspiradas de la Escritura) acerca del ministerio de Dios. Poseen valor propio, verdadero, analógico, pero siempre aproximado; el misterio, en efecto, es siempre insondable. Por esta razón se puede y se debe decir siempre que cualquier producción tendrá que aceplar la crítica de " "ralta de precisión teológica." La Humani generis, que tanto resalta el valor de las fórmulas, recuerda que pueden ser períeccionadas (perfici: AAS $42,1950,566)$, lo que equivale a afirmar que siempre pueden mejorarse en precisión.

Me parece que se ha escogido mal el ejemplo del sincretismo. Hago alli un esfuerzo conscieme de precisión terininológica muy delallada. Empiczo reconociendo la complejidad del renómeno y la ambigüedad del término, citando el Vaticano II: "hay que alejar toda especie de sincretismo y de falso particularismo" (Ad Gentes, 22/942; Iglesia: carisma y poder p. 146). Presento las distintas tendencias de la investigación y el esfuerzo por recuperar su sentido positivo, esfuerzo realizado en los últimos años de la historia del cristianismo, por la sociologia religiosa y la antropología culıural (c饣. la bibliografia citada en las pp. 145-146).

A continuación, para mayor claridad y superación de la ambigüedad, presento las distintas definiciones con sus correspondientes explicaciones e insuficiencias: sincretismo como suma, como acomodación, como mezcla, concordismos, Iraducción y refundición (pp. 147-149). Tomo sólo esté último signnilïcado: "se Irata de un largo proceso de producción religiosa casi imperceptible; la religión se abre a las distintas expresiones religiosas, las asimila, las reinterpreta, las refunde a partir de los criterios de su propia identidad" (Iglesia: carisma y poder, p. 149).

Este concepto positivo es el que yo asumo; intento demostrar con la histo- 
ria del cristianismo antiguo, en cilas de Origenes, Justiniano, Aguslin, Gregorio Magno y otros que la fe cristiana, sin perder su identidad ha hecho propios, enriqueciéndose, elementos religiosos ajenos.

Decididamente no consigo comprender cómo después de tantas explicaciones pueden surgir todavia ambigüedades. La historia de los dogmas está llena de ejcmplos de palabras con significados ambiguos, aunque rodos ellos querian explicar la misma verdad de fe. Asi, la palabra Iransubstanciación; según $Y$. Congar, santo Tomás no la conoce, ni siquiera el misal de su tiempo, aunque el Concilio Laterano (1215) la usa oficialmente. Las expresiones comunes eran transformación y conversión. Podriamos citar tambièn palabras-clave de la teologia comu clogna. hipóstasis, ius divinum, anatema sit, fides el mores, etc.

¿Por qué me interesa valorar positivamente el sincretismo? Ya lo indiqué al principio de mi defensa: el catolicismo romano está en contacio con la impresionante vitalidad de las religiones alro-brasileñas y con otras manifestaciones de la religiosidad popular que asimilan elementos de la tradición cristiana o viceversa. ¿Cómo valorar pastoralmente este problema? Se precisa una cierta apertura teológica para no perder la oportunidad de una posible expresión del evangelio que enriquezca al calolicismo latinoamericano con tonalidades africanas y amerindas.

Se me podria objetar: ¿por qué no ha utilizado el término inculturación? Lo evito porque coloca el acento sobre la cultura. La fe asume también códigos culturales. Pero quiero permanecer fiel al fenómeno que estamos afrontando en Brasil: se están asimilando elementos religiosos de otra cultura y no solamente sus códigos laicos. Al mismo tiempo la expresión sincretismo me parecía útil desde el momento en que llegaba purificada de sus ambigüedades históricas, ya hoy curso de superación.

\section{Utilización de las ciencias humanas y primado de la praxis}

El material utilizado en este ensayo es muy variado, hisıbrico, filosofico, político y sociologico. El uso de las ciencias humanas en teología es, en principio, legitimo. Pero estas ciencias tienen que ser probadas criticamente (no sean simples ideologias) y, sobre todo, las tiene que iluminar y guiar la luz de la fe, la ratio formalis de la teologia. Nos preguntamos: ¿el discurso de estas páginas esıa guiado por la fe o por principios ideológicos (de cierta inspiración neo-marxista)? El trabajo teológico tiene sus propias fuentes y exigencias que no son debidamente aplicadas en su libro. A menudo se presenta el contenido no tanto a la luz de la revelación, la tradición y el magisterio, como del primado de la praxis; propone como fin no la escatologia cristiana sino una cierta utopia revolucionaria extraña a la lglesia.

El objeto de la teología es Dios, el Dios revelado; pero no solo El, lo son también todas las cosas en cuanto vistas a la luz de Dios. Asi lo enseñaba santo Tomás de Aquino en la Summa Teologica y ioda la Iradición teoligica (cf. S. 
Th. p.l,q 1,a.7). Esto significa que también es propio de la teología hablar de la hisıoria, politica, cuonomía, sociologia y cualquier cosa que se contemple la luz de Dios. Creo haber cumplido con clara conciencia esta exigencia de la teologia.

Es mi estudio Cómo hacer teología a partir del cautiverio y de la liberación afirmo claramente: "la teologia de la liberación parte decididamiente de la fe. Esta es su primera palabra; en el acto de captar la realidad en su iniquidad y en la opción por las mayorias humilladas resulta vivo el horizonte de la fe en el (juc sc mueve vilalmemte el cristiano." (c. Teologia do cariveiro e da liberaçar. Perripolis, 1980, 30.32). Por lo lanto no le basla a la teologia con conscriar su ratio formalis. Cuando, por ejemplo, piensa sobre realidades complejas y "seculares" (la sociedad, los mecanismos del empobrecimiento, las organizaciones populares y la politica del trabajo, la función del estado, etc.) necesita conocer analitica y criticamente estas realidades. De lo contrario se mantiene una visión ideológica, empírica, ingenua, utópica o periodística que dañará luego el juicio teológico.

Esta previa operación intelectual (que en el cristiano se da siempre en el horizonle de la fe viva) sirve de base para un razonamiento teológico que se pretende sea serio. Esto no significa que el teólogo politice o socialice la fe. Sólo asegura la seriedad de su razonamiento; seriedad que exige la misma naturaleza intrinseca de la leologia y los mismos cristianos conscientes.

Una vez descifradas estas realidades con los instrumentos del análisis crítico (y por eso no ideológico), el teólogo pasa a leerlas a la luz de la fe, de la tradición, del magisterio y la razón teológica. Y, por tanto, hace teología de la politica, teologia del proceso de liberación, teología del fenómeno socioreligioso, del sincretismo.

La tradición teológica enseña que los teólogos de todos los tiempos han hecho esta distinción. En la misma definición de teologia encontramos las razones que exigen conocer la ciencia. Santo Tomás afirma con razón en la Summa contra gentiles: "el conocimiento de la naturaleza de las cosas ayuda a desiruir los errores en Iorno a Dios... Se equivocan quienes afirman que no tiene nada que ver con la verdad de la fe la idea que uno tenga de las creaturas, mientras piense correctamente de Dios... En efecto, los errores sobre las creaturas rebotan a una lalsa idea de Dios"' $(1,2$, c.3).

La sociedad, la política, la economia no dejan de ser en última instancia criaturas de Dios. Si queremos hablar de estas realidades en la perspectiva de Dios debemos conocer la naturaleza y sus mecanismos de funcionamiento. Sólo entonces el discurso teológico resultará serio y no repetirá cosas sabidas, fruto de todo conocimiento superficial y francamente ideológico.

En el capitulo de mi libro Iglesia: carisma y poder. "Características de la Iglesia en una sociedad de clases" (pp. 172-195) remarco esta perspectiva: en la misma y única lglesia coexisten dos dimensiones, la institucional y la sacramental. No son realidades distintas, sino dos ópticas diferentes para ver una misma cosa, una como realidad teologica y salvífica (sacramento), la otra como realidad concreta e histórica (institución). 
En mi análisis me atengo al primer significado (institución), porque el otro (sacramento) se supone aceplado y conocido ya por los fieles. Ahora bien, esta institución que es la Iglesia se inserta en un complejo mayor que en nuestro caso es la sociedad capitalista y de clases. ¿Cóno incide este hecho en la Iglesia? ¿Qué características toma la Iglesia cuando, partiendo de su identidad teológica y divina, debe encarnarse dentro de estos limites?

El interés de semejante análisis no es sólo científico, sino tambièn teológico porque, como escribo en ese capílulo, "la institución es vehiculo del sacramento; la visibilidad social de la Iglesia hace concreta la gracia y el reino de Dios" (p. 175). Creo que esta perspectiva encuentra su legitimidad teológica en la Lumen gentium (n.8, y todo el cap. 2 sobre el pueblo de Dios). Respondiendo a la cuestión planteada por la carta del cardenal Ratzinger pienso que mi razonamienı está guiado por la fe y respeta las exigencias del irabajo teológico.

En la carta me dice tambièn que presento el contenido preferentemente a la luz de la primacía de la praxis. Por praxis entiendo generalmente en el libro Iglesia: carisma y poder, la vida concreta de la lglesia con sus problemas, con sus testimonios y su búsqueda, como ya dijeron los obispos de Puebla en el primer capitulo del documento final sobre la situación pastoral del continente.

Se trata en primer lugar de observar la realidad, verla en plenitud, en el horizonte más amplio de la fe; plenitud que Dios habila como afirmábamos antes. Luego debe interpretarla a la luz de la revelación, la tradición, el magisterio y la reflexión teológica.

¿No lo hacia así Jesucristo? ¿No es acaso esto lo que enseñan sus parábolas? El conocía a la mujer que amasaba el pan, sabia como aciúa un administrador corrupto, como se siembra la semilla. Jesús partia de esta realidad humana, aprendida en la práclica de la vida, y desde ahi hablaba del reino, del Padre, de la conversión.

En mis trabajos acostumbro a seguir este procedimiento melodológico que ha sido ampliamente aceptado por los obispos en los documentos de nuestra conferencia episcopal y en la pedagogia popular de las comunidades eclesiales de base.

¿Por que alimentar prejuicios contra la "primacia de la praxis"? La pra$x$ is de la fe está teológicamente provista de los más elevados significados. Seremos juzgados precisamente en base a esı praxis; lo dice el Señor (MI. $7,21 ; 25,31-46)$. La salvación viene más del hacer que del decir. Entonces ipor qué no valorar teológicamente lo que es inás decisivo en orden a la salvación y la perdición? No se hace teologia para lucirse, sino para generar un amor eficaz, lúcido e inteligente.

Considero injustificado e incomprensible afirmar que yo "propongo como fin no una escatología cristiana sino una cierta utopia revolucionaria ajena a la Iglesia." ¿Qué pido yo en el libro Iglesia: carisma y poder? No pido un proyecto revolucionario, sino lo que propone el evangelio en términos de relaciones sociales justas y de un poder que preste sus servicios: que todos sean hermanos (Mt. 23,8); que se utilice el poder como servicio (Mc. 22,27); que no 
falte el diálogo en los conflictos intraeclesiales (Mt. 5,$23 ; 18,15-17$ ) y que exista un compromiso efectivo hacia los pobres como lo tuvo y lo quiso Jesucristo.

Si esto se realizase en nuestra sociedad brasileña, donde reina uno de los capitalismos más salvajes del mundo, con todas las consecuencias que castigan al pueblo, sería una auténtica revolución. Un concepto preciso de la escatologia cristiana (sobre ella escribí todo un libro Vida más allá de la muerte, Petropolis, 1983) pide que los bienes del reino se anticipen y encuentren ya aqui cierıa realización histórica.

\section{Respuestas relativas al contenido doctrinal}

\section{La esIruclura de la Iglesia}

Después de conteslar a las cuestiones sobre el método, paso a explicar las objeciones que plantea la carta del cardenal Ratzinger sobre el contenido doctrinal. Afronto por separado las cuestiones siguientes: la estructura de la Iglesia; la concepción del dogma y de la revelación; el ejercicio del poder sagrado.

Ud. afirma que Jesús no determinó la estructura de la Iglesia; sino que es más bien el resultado de una necesidad sociológica inevitable. El modelo estructural de la lglesia católica no seria el único posible ni debería pretender identificarse de forma exclusiva con la Iglesia de Cristo, porque ésta puede subsistir también en otras Iglesias cristianas (cf pp. 79; 124-125, elc.). De aqui se deriva una concepción relativizante del catolicismo frente al protestantismo. Tratándose de "dos mediaciones" imperfectas del evangelio, una no debe excluir a la otra, sino que han de comprenderse más bien como acentos o estilos diferentes de vivir la totalidad del cristianismo (cf p. 132). Por lo tanto resultaría ser un error histórico la exclusión del protestantismo, porque al mismo tiempo se excluiría tambièn la posibilidad de la verdadera critica dentro de la Iglesia y el catolicismo podría transformarse en una ideologia reaccionaria, violenta, represiva, llegando a pretender la infalibilidad y alejándose así del evangelio (cf p. 141).

Posiblemente juzgue Ud. exagerada y unilateral esta interpretación de su pensamiento. Nos preguntamos, no obstante, si ésta no es la interpretación justa, dónde está el motivo de una agresión tan despiadada y radical contra el modelo institucional de la lglesia católica. ¿Qué sentido tiene tanto celo por reducir sus estructuras a caricaturas inaceplables? ¿El nuevo modelo alternativo que defiende, prevé las mismas estructuras que Ud. tanto contesta?

En su interpretación relativizante de la Iglesia católica - fundamento de su crítica radical a la figura histórica de nuestra lglesia - Ud. apela al Concilio presentándose como intérprete del pensamiento conciliar. Pero la interpretación que Ud. propone de la Constitución dogmática Lumen Gentium n. 8, no sólo es evidentemente ralsa, sino que está en abierta contraposición con las verdaderas intenciones del texto, como se puede 
observar en las fuentes publicadas sobre dicha Constitución (cf también el Decreto Unitatis redintegratio n. 3-4). La auténtica doctrina de la Iglesia sobre este punto fue precisada en la declaración Mysterium ecclesiae de donde recogemos las afirmaciones siguientes: "una sola es la lglesia que Nuesıro Señor dejó al cuidado pastoral de Pedro;" "'esta Iglesia de Cristo, constituida y organizada como sociedad en este mundo, subsiste en la Iglesia católica;" "sólo... mediante la Iglesia católica de Cristo, instrumento universal de salvación, es posible entrar en la plena posesión de lodos los medios de salvación," "por lo tanto, los ficles no pueden intaginarse la Iglesia de Cristo como la suma - diferenciada y, en cierta manera, también unitaria - de las Iglesias y comunidades eclesiales; ni pueden pensar que la lglesia de Cristo no exista hoy más en otro lugar y que, por eso, tiene que ser solamente objeto de búsqueda por parte de todas las lglesias y comunidades" (cf. AAS LXV, 1973, pp. 406-407; Ench. Vat. II, IV, nn. 2565 s.). Estas explicaciones dadas por la Congregacion para la Doctrina de la $\mathrm{Fe}$ en 1973, son ya una respuesta a las posiciones que Ud. sostiene.

Respondo a este largo razonamiento en ires partes.

\section{a) Jesis y las esiructuras concrelas de la lglesia}

Nunca he afirmado que Jesús "no ha determinado la estruclura de la Iglesia; y que sería más bien resultado de una necesidad sociológica inevitable." No se cita ninguna página de referencia. Probablemenle se confunda mi posición con la de Rudolf Sohm que yo critico (pp. 114-116: "el catolicismo surgió y debía surgir de una férrea necesidad," Iglesia, carisma y poder, 110). Aquí transcribo mi postura: "la doctrina común afirma que Jesús lundó la Iglesia. Esta verdad pertenece al depósito inalienable de toda la fe cristiana y eclesial. De todas maneras tenemos que determinar en qué forma concreta Crislo quiso y fundó su Iglesia. No todos los elementos institucionales de la Iglesia se remontan a Jesús... Cristo introdujo realidades que más tarde habrian constituido el fundamento de la lglesia: la institución de los doce, el bautismo y la cena eucaristica. Pero esios elementos no constituyen todavía toda la realidad de la Iglesia" (Iglesia: carisma y poder, pp. 222-223).

A continuación hablo de misión, de ingreso de los gentiles, de la decisión de los apóstoles de no obligar al cumplimiento de las leyes judias, elc. La Iglesia concrela e historica no nació directamente del Jesús histórico con indos sus élementos. La teología siempre ha insistido en la imporiancia de pemtecostés respecto a la constitución de la Iglesia.

M. Schmaus, teólogo moderado y eclesial, escribió en su manual La fe de la Iglesia: "es cierto que en los dias de la vida de Jesús no existia lglesia alguna. Esta se formó sólo direclamente en virtud de la experiencia de pascua y de la venida del Espiritu que tuvieron los discípulos. Jesús preparó la lglesia durante su vida terrena con su existencia, palabras y acciones, pero no la instituyö" (vol. 4, Petrópolis, 1978, p. 26).

Cuando discuto la problemática del Frïhkatholizismus (el nacimiento del catolicismo con las estructuras religiosas, dogmáticas, litúrgicas y canónicas) en diálogo con la corriente protestante, retorno a la problemática en términos 
históricos: ¿hasta qué punto estas determinaciones tan definidas historicamente habrian sido pensadas por Jesús? Evidentemente podemos suponer que nadie osaria afirmar que Jesús, en su vida terrena, creó cardenales, curias diocesanas, consejos pastorales, códigos canónicos con sus especificaciones, como los procesos matrimoniales o los procesos para nombrar y destituir parrocos, como encontramos en el nuevo código de derecho canónico. Este es el sentido de mi libro en las pp. 122-124. Nadie niega la voluntad de Jesús de tener discípulos que promovieran su causa a partir de un nucleo fundamental, del mensaje, de las estructuras, de las personas (los doce y Pedro).

\section{b) La Iglesia de Cristo, la Iglesia calólica y las demás iglesias cristianas}

Es preciso reflexionar también sobre esta afirmación: "el modelo estructural de la Iglesia católica no sería el único posible." Ahora bien, por modelo entendemos la forma histórica mediante la cual los elementos estructurales de la Iglesia han tomado un perfil especifico distinto de otros. Algunos elementos estructurales son la doctrina, el culto, la acción en el mundo, la misión universal y el gobierno que confiere a todos los elementos organicidad, unidad y animacion. Pero estos elementos estructurales se organizan de forma diferente en la Iglesia católica latina y en la católica ortodoxa. Incluso en la lglesia católica latina existieron perfiles diversos de lglesia si tenemos en cuenta los siglos de existencia cristiana. Uno es el perfil de la lglesia del norte de Africa con San Cipriano y San Agustin; olro el de la Iglesia de la época carolingia; también es distinto el perfil de la Iglesia en época feudal con lnocencio III y san Francisco de Asís; y por fin distinto es el perfil de la Iglesia que emerge del Vaticano II, Medellin, Puebla. Este pluralismo en las formas de expresión cultural manifiesta la riqueza de la unidad de la fe de la misma y única Iglesia de Jesucristo.

También la segunda parte de la afirmación merece atención: "(el modelo estructural de la iglesia) no deberia pretender identificarse de forma exclusiva con la Iglesia de Cristo, porque ella puede subsistir también en otras iglesias cristianas." Con relación a este problema me dirige la crítica siguiente: "la interpretación del $\mathbf{n . 8}$ de la constitución dogmática Lumen Gentium no solo es claramente falsa sino que está además en abierto contrate con las verdaderas intenciones del texto, como se puede comprobar en las fuentes de dicha constitución (cf. también el decreto Unitatis redintegratio, nn. 3-4)." Se alude luego a la Mysterium ecclesiae, compuesta de textos del Vaticano II, que vuelve a proponer una misión más orgánica.

Sobre esto tengo que afirmar que mi postura no es falsa; coincide perfectamente con el n.8 de la Lumen gentium y con la Mysterium ecclesiae. Ya en mi tesis doctoral "Die Kirche als Sakrament" de 1972 consagré al tema un capitulo entero (pp. 413-426). Ni la Lumen gentium, n. 8, ni la Mysterium ecclesiae identifican pura y simplemente la Iglesia de Cristo con la Iglesia catolica. Además los textos no afirman jamás est (es), sino subsistit in (subsiste en, alcanza su realización concreta). Por eso afirmo que la identificacion no es exclusiva. Las actas publicadas sobre la discusión de este famoso n.8 explican exactamente las razones por las que se sustituyb el est por el subsistit in. En el esquema sobre la Iglesia de 1963 existía esta identificación: "Haec igitur eccle- 
sia... in hoc mundo ut societas constituta et ordinata, 'est' ecclesia catholica..." Tras largas discusiones en la comisión teológica, ya el esquema de 1964 sustituía el est con el subsistit in, con esta razón: "loco 'est'...dicitur 'subsistit in' ut expressio melius concordet cum affirmatione de elementis ecclesialibus quae alibi adsunt"' (cf. Typis Polyglotis Vaticanis, 1964; comparar con los textos publicados en Scholastik, 40, 1965, 352-388). Todo esto se encuentra en mi libro Iglesia: carisma y poder, p. 125 y en la nota 42 de la misma página. El decreto Unitatis redintegratio explica dónde se encuentran estos elementos eclesiales, fuera del ámbito instifucional de la lglesia calólica romana: "entre los elementos o bienes del conjunto de los cuales se construye y vivifica la misma lglesia, algunos - bastantes y señalados- pueden encontrarse fuera de los confines visibles de la Iglesia carblica"'(n.3/761). Por causa de estos elementos el Concilio habla de iglesias (Unitatis redintegratio, n. 3/763; 764 etc.).

La Iglesia católica posee "la plenitud de los medios de salvaciin," pero hay medios que se hallan también fuera de ella; por ello y con razón dice la Unitatis redintegratio que los miembros de las iglesias aunque sin la plenitud, están constituidos en una cierta comunión, aunque imper $\int e c t a$, como la lglesia católica" (n.3/760).

La unidad entre la lglesia de Crisı y la Iglesia católica no es mecánica y estática. La Iglesia de Cristo se realiza en la Iglesia católica de la manera que corresponde a la realidad constitutivamente dinámica de la naturaleza sacramental de la Iglesia. En su institucionalidad visible la Iglesia catoblica no es senora y poseedora de todo el "misterio" de la única lglesia de Jesucristo. Es una realización de servicio humilde, "santa pero siempre necesitada de purificación" (Lumen gentium, n.8/22) sin poseer adecuadamente el misterio, sino poseyéndola él.

En en este contexto en el que afirmo en mi libro: "la Iglesia católica, apostólica y romana, por un lado es la de Cristo, y por olro no lo es. Es la Iglesia de Cristo, porque aparece en el mundo en esıa mediación concreta. Pero no lo es en cuanto no puede tener la pretensión de identificarse de forma exclusiva con la Iglesia de Cristo, pues ésta puede subsistir también en otras Iglesias cristianas"' (pp. 124-125).

La cita del cardenal Ratzinger en su carta omite la primera parte de mi frase. Así se ha llegado a distorsionar mi pensamiento. Repito, no digo que "la Iglesia de Cristo no subsiste en ningún sitio." Subsiste en la Iglesia católica, está alli, pero en una forma concreta de sombra y de fidelidad (Lumen Gentium, n.8/23). Por la falta de unidad que existe en el conjunto del fenómeno cristiano, podemos sostener que todos tenemos la obligación de convertirnos; de hecho, la separación de la plena comunión de la lglesia católica ocurrió algunas veces no sin culpa de las personas de ambos lados (Unilas redintegratio, n.3/760); somos mediaciones imper(ectas frente al evangelio que es Jesús en persona, testimoniado por los cuatro escritos evangélicos. Si no fuese asi, la Iglesia no necesitaría convertirse al evangelio cada dia, mañana y noche.

Espero que estas aclaraciones expresen con nitidez mi posición acorde con 
la doctrina oficial de la Iglesia.

c) La cuestión del protestantismo

En este punto de su carta el cardenal confunde los problemas: imipide así que se comprenda el sentido de mi exposición. Se trala de la famosa controversia confesional que surgió a raiz. de la Reforma: ¿qué es el calolicismo? Para los protestantes, el catolicismo es decadencia del evangelio. Frïhkutholizismus es precisamente la expresión acuñada para subrayar la diferencia entre el tiempo del evangelio y el de la organización eclesiáslica, origen del catolicismo tomano.

La discusión hermenéulica de los últimos años llevó a una mayor profundización del problema, mostrando que el evangelio puro y el cristianismo genuino no existirán janás sin mediaciones culturales, doctrinales y lingüisticas. En esta línea a lirmo: "la realización concrela del cristianismo en la historia se Ilama calolicismo e Iglesia" (Iglesia: carisma y poder, p. 123). El cristianismo se identifica en las mediaciones históricas, pero no se identifica con las mediaciones históricas, es decir, éste alcanza su concretización mediante el proceso de encarnación, pero ninguna concretización agola el cristianismo (cf. $\mathrm{Hu}$ manae generis, AAS 42, 1950,568).

Mi afirmación fundamental consiste en lo siguiente: ser calólico implica una doble actitud, una afirmativa con la que sc asume la historia en forma de dogma, derecho, disciplina litúrgica; la otra negativa con la que no se identifica el misterio (y la $\mathrm{re}$ ) con ninguna de estas expresiones, de forma completa y plena (cᄃ. p. 129). Ambas actiludes tienen que coexistir y componer la existencia calólica. La palabra de la tradición que recoge estas dos perspectivas es sacramentum: una rcalidad visible que contiene otra invisible. El misterio existe en el sacramento, pero lo supera. Halla en el sacramento una identidad y una no identidad.

Históricamente constatamos dos acentos que nacen de la dialéctica del mismo sacramento: una subraya más el lado invisible del sacramento visible, y la otra el lado visible del sacramento invisible (res sacramentum). Lo ideal seria que ambas dimensiones se mantuvieran y vivieran en inulua implicación (pericoresis o dialéctica).

En la historia encontramos el catolicismo romano y el protestantismo como expresiones sociologicas de la fe cristiana. Para el problema que analizamos no sirve, para discutir, cuál de ellos es el portador de la verdad de Jesús. Ambos son realidades históricas. Sociológicamente uno y olro muestran acentos o estilos diversos de vivir la tolalidad del cristianismo. Me parece que el catolicismo se distingue por su valiente afirmación cle la iclentidad sacramental y el protestantismo por la no identidad sacramental. El catolicismo acentúa la encarnación, la penetración en las distintas culturas, la fundación de un "orden religioso." El protestantismo enfaliza el distanciamicnto cle la cultura, la pureza del cvangelio, la trascendencia de la revelación frente a cualquier expresión (eológica (cf. la teología de Karl Barth). Es evidente que ni el catolicismo ni el protestantismo excluyen los dos polos; atmbos intentan mantener la identidad y la no-identidad sacramental. Con todo uno y orro acentúan polos dife- 
rentes, dando origen a estilos distintos de vivir la fe cristiana.

Con esto no quiero relativizar el catolicismo. Otro problema distinto es interrogarse sobre la legitimidad teológica del protestantismo. Yo no afronto este problema. En lo que se refiere a "los acentos o estilos diversos de vivir la cotalidad del cristianismo" (p. 132), no me coloco en el campo dogmático sino en el puramente histórico. Confrontando catolicismo y protestantismo, asi como he hablado de dos estilos, asi también podria hablar de dos o más estilos de vivir la fe cristiana tambièn denlro del carolicismo. En efecto, un monje católico en el desierto vive un estilo propio y de caracteristicas especificas, como, por ejemplo, el padre Charles de Foucauld. Igualmente el estilo de un obispo que vive en la selva amazónica, como Dom Moacyr Grechi, será distinto del de un obispo católico que viva en la ciudad industrial de San Bernardo, como D. Cláudio Hummes. Aunque sean estilos diferentes, cada uno trala de abrirse a la totalidad del evangelio y abrazar la totalidad del cristianismo.

Ambas expresiones, la calólica y la prolestante, pueden prestarse a deformaciones que yo llamo patológicas. Todo lo sano puede enfermar. El protestantismo corre el peligro de distanciarse de la historia; el catolicismo, el de perderse en la historia. La tentación de los católicos está en no ser suficientemente criticos frente a las encarnaciones culturales que pueden asumir. Los protestantes, nuestros hermanos, podrian ayudarnos en nuestra tarea de distanciamiento critico y de liberación de algunas mediaciones para inserirnos en otras mediaciones más apropiadas al evangelio en el tiempo.

En un contexto semejante es donde afirmo que "fue un error histórico la exclusión del protestantismo de la Iglesia católica, porque no se excluyó solo a Lutero sino que fue también eliminada la posibilidad de una critica real a la contestación del sistema en nombre del evangelio" (Iglesia: carisma y poder, p. 141).

Así como la fe puede deformarse en fideismo, lo natural en naturalismo, así también lo católico puede degenerar en catolicismo, cuyas formas históricas fueron finamente descritas por H.Gorres y B. Welte ("Pathologie des Katholischen Christentums," en Handbuch der Pastoraltheologie, I1/1, Freiburg, 1966, 277-343 y el libro de B. Welte, "Wesen und Unwesen der Religion," en Auf der Spur des Ewigen, Freiburg, 1965, 279-296).

A este respecto la carta del cardenal transcribe de forma equivocada una cita mia, provocando un grave disfraz de su significado: "el catolicismo podria transformarse en una ideología reaccionaria, violenta... etc." Mi texto habla de "la mentalidad catolicistica y no de calolicismo. Veamos el texto completo: " $\%$ catolicistico puede transformarse en una ideologia lotalitaria reaccionaria, violenta, represiva y hoy invocada por notorios regimenes totalitarios en el poder en varios países de América Latina. No hay cosa más alejada y extraña al espiritu evangélico que la pretensión del sistema catolicístico de la infabilibilidad ilimitada" (y no como dice el texto de la carta: "la pretensión de ser infalible;" la infalibidad, en efecto, existe, y yo acepto el dogma de la infalibidad) (Iglesia: carisma y poder, p. 141). 
Considero que la carta del cardenal ha expuesto mi pensamiento de forma poco feliz y como él mismo sospecha de manera "exagerada y unilateral." Espero que estas aclaraciones hayan dado mayor luz a mi postura expuesta en el libro Iglesia: carisma y poder, donde digo que "aunque la mentalidad catolicística pertenece a la historia del catolicismo y como tal debería ser reconocida por los caiólicos...: muchos síntomas patológicos son manifestaciones de un principio verdadero, patologias que no llegan a engullir la fuerza positiva de la identidad del calolicismo" (p 141).

Finalmente queda la cuestión dogmática del calolicismo, la de no ser una expresión particular, sino un sistema abierto a todas las experiencias legítimas de la le, incluidas aquellas que los sociólogos e historiadores podrian designar como la forma prolestanle del cristianismo. El llamado "principio protestanเc," según el padre Tillich, perteneceria a la esencia del auténtico catolicismo.

\section{La concepción del dogma y de la revelación}

Dice la carta del cardenal Ratzinger:

"En la estructura palológica de fondo del catolicismo romano" Ud. subraya de manera particular el "dogmatismo" de las verdades y la comprensión "doctrinaria" de la revelación, que frecuentemente condujo y conlinúa llevando todavía hoy hasta la violación de los derechos de los fieles (c[ np. $61 \mathrm{ss}, 74-75$, etc.).

Frente a tal "dogmatismo" Ud. propone una nueva concepcion del dogma. "La afirmación dogmática es legitima y también necesaria a causa de la amenaza de herejia y de perversión de la conciencia cristiana. Pero en su rormulación existe una clave de desciframiento válida para un determinado tiempo y determinadas circunstancias. Cuando se olvida esta instancia histórica y temporal y se pretende hacerla valer, en su formulación, para todos los tiempos, y de manera exclusiva, entonces ella se tranforma en obstáculo para las necesarias y nuevas encarnaciones del cristianismo" (c饣. p. 127-128; cl lambién el conlexlo).

\section{a) El dogma y sus formulaciones}

Cuanto hemos expuesto en el apartado precedente sobre las posibles distorsiones en el interior del calolicismo, que, por lo dicho, se manifiesta como catolicista, nos introduce en la respuesta a las cuestiones relacionadas con el dogma y la revelación. El dogma representa algo verdadero y sano para la fe; jamás puse en duda esta realidad. E.l dogmatismo en cambio resulta ser una patología. El dogmatismo es una actitud rígida de la persona que le impide ver las dimensiones más elevadas del misterio divino que trasciende las expresiones dogmáticas. La revelación es un acontecimiento salvífico en el que Dios, espontáneamente, se entrega a la persona humana; es profundamente liberadora. La revelación divina, como veremos a continuación, se traduce en doctrinas y formulaciones de la verdad. Por lo tanto, la revelacion divina no se confunde con la formulación humana de la verdad. Su identificación conduce a una mentalidad doctrinaria que busca inculcar esas verdades a lodos, cuando, 
por el contrario, la vida no exisle sólo de verdades felizmente encontradas, sino de búsqueda; de formulaciones de hipótesis, de insinuaciones.

Tiene que valer para la teologia lo que vale para la Escritura. Como declaró la Comisión Biblicá en 1915: "lo que el hagiógrafo afirma, anuncia e insinua tiene que aceptarse como afirmado, anunciado e insinuado por el Espiriu Santo' (EnB 433).

El padre P. Benoil lo comenta asi. y su comentario vale tambicn nara la teolugia: "en la Bíblia, junıo a la afirmación calcgórica exisıe ıambién la propuesta de una probabiliclad, una posibiliclad, una simple conjelura o incluso de una duda" ("L'inspiration." en Initation biblique. Tournai, 1954, 37: Iglesia: carisma y poder, 6y, nola 16).

Semejantes doctrinas dogmáticas y doctrinalistas llevan lácilınente a la violación de los derechos de los fieles, de la expresión pluralista de su fe, en el marco aceptado de los dogmas y de las expresiones de la revelación (cf. $61 \mathrm{~s}$; 73-76).

Para remediar tales exacerbaciones nunca he propuesto "una nueva concepción del dogma," como señala la carıa. Tengo que decir también que no he escrito ningun tratado sobre el (ema, para que se pueda hacer una alirmación tan apodictica; afronlo el rema, en passant en media página (127-128). Además mi postura no es nueva; es común y se encuentra en los manuales. Véase, por ejemplo, Y. Congar, La foi el la théologie (Descléc, 1962. en especial e] capítulo Le dogme et les formules dogmatiques, pp. 54-71).

Por lo demás, tal como señala el texto que cila la carta del cardenal, considero que la declaración dogmática no sólo es legitima, sino incluso necesaria (p. 127 y en otras parles). Intentemos ser claros: ¿de qué se trata, a fin de cuentas? ¿Dónde está el problema? En la relación enıre el dogma (verdad) y sus formulaciones (expresiones lingüisticas). Aqui soy claro y no veo que es lo que se puede objetar a afirmaciones como ésıa: "la obligatoriedad del dogma esı́a ligada a la verdad enunciada, no a la exclusividad de sus formas de enunciarla (128). Una cosa es la verdad, que es divina, y otra su expresión lingüistica que es humana. Se da una analogia con el dogma crisıológico, con la conciencia de que el Verbo (en nuestro caso, la verdad divina) sobrepasa infinitamente a la humanidad (en nuestro caso, las expresiones lingüisticas). Las expresiones humanas de la verdad divina están ligadas a un tiempo y a un espacio en cambio continuo. Por esto, sabiamente enseñaba santo Tomás: "Aclus credentis mon" terminatur ad enunciabile (la fórmula) sed ad rem (la verdad divina)" (Quaest. disp. De veritale, q. 14, a.8, ad 5).

La verdad de Dios es universal; nuestro lenguaje expresivo (clave de lectura) es particular. Cuando la Iglesia es misionera en medio de culturas distintas de aquellas en donde nació la fe, tiene que realizar un esfuerzo de traducción para que los hombres reciban la verdad de Dios en su propia lengua, como enseña el acontecimiento de pentecostès: "oimos anunciar en nuestras lenguas las grandes obras de Dios"' (Act. 2,12). En todas las traducciones hay que salvar el significado que la lglesia ha querido dar siempre y transmitir en sus formulaciones. Es además lo que nos enseña el Vaticano I: Sacrorum dogmatum 
is "sensus" est perpetuo retinendus, quem semel declaravit sancta inater ecclesia (DS 3020. C F. 3043). En la historia de la Iglesia pucden cambiar las palabras y las expresiones, con tal de que se conserve y iransınila el mismo sıgnificado.

La historia del dogma es rica en ejemplos en los que se ve la irayectoria agitada de algunas expresiones fundamentales de la teología, hasta que se fijó el significado preciso que la Iglesia queria darles. Tomemos como ejemplo el término decisivo omoúsios (la unicidad de naluraleza en el Padre, el Hijo y el Espiritu Sanio). Primero reivindicó la palabra de Dionisio de Alcjadría (año 206); a causa de Pablo de Samosara, el vocablo fue condenado por el Concilio de Antioquia (el año 269); Nicea (325) lo declaró oficial y San Atanasio lo difundió ardientemente; con todo, para el santo, lo más imporıanıe del término omoúsios era el significado que se le alribuia (la divinidad verdadera de Jesús); si se salvaguardaba este significado no cuestionaba de forma intransigente el término. Atanasio escribía al grupo de Basilio de Ancira, que rechazaba el término omoúsios, pero aceptaba el significado de la divinidad de Jesús: "quienes aceptan todo lo que se ha escrito en Nicea, a pesar de los escrúpulos relativos al término omoúsios, no deben ser tralados como enemigos... yo discuto con ellos como un hermano discute con otros muchos hermanos que piensan la misma cosa que yo, aunque difieran en las palabras" (De sjnodis, 41: PG 26,785). Por oira parte san Hilario atacó a los herejes que usan el término omoúsios con un significado distinto, lo que demuestra que más que el término lo importante es la verdad pensada (cᄃ. Contra Auxentium, PL 10,613). Lo mismo podría decirse del término hipóstasis, ousia y prósopon, como, por otro lado, se discute en una carta de san Jerónimo al Papa Dámaso (Ep. 15: PL 22,356-357).

Concluyamos, en términos de evangelización no debemos ser rigidos en las fórmulas; debemos empero actuar de manera que el mismo sentido de la fe pueda sin impedimentos, encarnarse en otras culıuras e incluso en olros esiratos sociales (ambientes populares, etc.).

\section{b) La revelación de Dios y las docminas acerca de Dios}

Sigue la caria del cardenal:

Seria igualmente necesario, en su opinion, una nueva comprensión de la revelación y de la fe. "Dios ante $10 \mathrm{do}$ no ha revelado proposiciones sobre sí mismo, el hombre y la salvación. El se ha revelado a si mismo cn su misterio, en su vida y en sus planes. La fe en su sentido primordial consiste en la adhesión total al Dios vivo y no simplemente en la aceptación de un credo a base de proposiciones. La doctrina tiene su función propia, pero la liene en un momento posterior o derivado. En la formulación de la doctrina sobre la revelación y la salvación intervienen variantes culturales y por tanto están de la parte del hombre. Las doctrinas cambian, como se ve en la misma Biblia, pero están articuladas de forma que permitan reconocer la presencia de la salvación y del Dios vivo" (cf. p. 79-80; cf. también el contexto).

¿Qué diremos de una relativización semejante de las formulas dogmáticas 
y de una semejante comprensión "pre-doctrinal" de la revelación y de la fe? Ciertamente dejarán el campo libre a nuevas encarnaciones y nuevas inculturalizaciones del cristianismo, sobre lodo si se acepta la peculiar pneumatologia, también discutible de las páginas 220 y siguienıes.

¿Pero con qué garantia? ¿Cuál podría ser el criterio para discernir la legitimidad de tales encarnaciones e inculturalizaciones? Si una fórmula dagmática no será ya válida en las nuevas culturas del mañana, icómo podrá serlo hoy frente a tantas y tan diversas culturas mundiales? Es verdad que Dios no nos ha revelado fundamentalmente proposiciones, sino a si mismo. vivo y salvador, pero el Dios de la revelación biblica no sería reconocible sin enunciados doctrinales.

La fe de la Iglesia, aunque no esıć ligada a una determinada sistematización leológica, sc expresa en un conjunto orgánico de enunciados normativos. Es verdad también que las formulaciones teológicas responden a problemas del momento histórico concrelo y se formulan con un vocabulario tomado de la cultura de su época; no obstante, sin comprometerse con la cultura del tiempo y debiéndose interpretar siempre con relación a la revelación, permanecen siempre verdaderas.

La posición justa en relación con la palabra de Dios, contenida en la revelación y conservada como depositum fidei por la lglesia, fue fijada por la constitución dogmática Dei Verbum del Concilio Vaticano 11.

Aqui se cita el n.10 y en relación a los teólogos el n.23. Acaba el texio:

A fin de que el depositum fidei pueda seguir su función de sal de la tierra que jamás pierde su sabor, tiene que conservarse en su pureza, sin resbalar como a Ud. le gustaria hacia un proceso único y dialéctico de la historia (cf. p. 130) y el primado de la praxis (cᄃ. pp. 73-74).

Mis afirmaciones son tan comunes en la teologia y en el mismo magisterio del Vaticano I y II que me maravilla ver que sea objeto de critica exigente y alarmante, como si el Espiritu Santo no estuviera en la Iglesia y en una especial asistencia al magisıerio para acompañar los procesos, ciertamente dificiles, de penetración del evangelio en las culturas del mundo. Si Dios acompañó el paso del judaísmo biblico (el mundo de Jesús y los apósıoles) al mundo grecoromano y luego al germánico y moderno, ¿cómo no va a acompañar la irayecIoria de la Te en Asia, donde vive más de la milad de la humanidad; en Africa, donde aún sufre cl siervo doliente, y en la América Latina oprimida y en busca de su liberación integral? No basta con preocuparse del propio tesoro; importa mucho tener siempre viva la perspectiva misionera y universalista. De lo contrario damos la impresión de no creer en la fuerza intrinseca del evangelio ni en la presencia del inismo Dios en el corazón de lodos los hombres, sus culturas, y creer mucho más en nuestros criterios y pavorosas iniciativas.

No se trata en absoluto de "una nueva comprensión de la revelación." Afirmo más bien que "la doctrina tiene su función, pero en un momento derivado" (Iglesia: carisma y poder, p. 80). ¿Por qué "en un momento derivado?" Porque es necesario distinguir el Dios que se revela (Deus revelans) de las formas con las cuales los hombres captan esta revelación de Dios o la 
forma que Dios mismo usa para que la acogen los destinatarios. Dios no agota su mislerio cuando usa palabras, hechos o personas para comunicarse. Decía muy bien el Vaticano 1I: "Dios, al revelarse a su pueblo... hablo con sintonia con la cultura propia de las diversas épocas" (Gaudium et Spes, 58/389).

La misma carta del cardenal me da la razón cuando dice, exactamente como yo habia dicho antes: "es verdad que Dios, ante todo, no nos ha revelado proposiciones, sino a si mismo, vivo y salvador."

Pues bien, esto es cabalmente lo que nos enseña el Vaticano II: Attamen placuisse... se insum revelare ac aelerna volumlatis suae decrela humano generis (DS 3004). El Vaticano II vuelve a la misma perspectiva: "por la divina revelación Dios ha querido manifesıarse y comunicarse a si mismo y comunicar los decretos eternos de su voluntad para la salvación de los hombres" (Dei Verbum, 11.6/167).

Basándome en la doctrina de ambos concilios hago resaltar la revelación como acto operativo de Dios: Dios mismo se autocomunica en un sentido primero y fundamental; luego, en un sentido derivado surgen las doctrinas sobre la revelación de Dios y sobre la realidad que èl nos ha desvelado (decreta). Para poner de relieve esta diferencia el mismo Vaticano Il modifica en la $\mathrm{De} i \mathrm{Ver}$ bum la redacción inicial que decia asi: Divina revelatione manifestantur ea quae, etc... por este otro: Divina revelatione Deus 'se ipsum,' etc..." (sobre este problema consultar Henri De Lubac, La revélátion divine. Commentaire du preéambule el du chapitre I de la constitution Dei Verbum du concile Vatican II. Paris, 1983, P. 129).

Es evidente que el oyente recibe la revelación del mismo Dios en base a su propio cuadro conceptual; cuando la revelación es escrita se comunica a través del texto canónico. Pero el Dios revelador es más que el texto inspirado. Este, el texto, será luego la Sagrada Escritura mediante la cual encontramos al Dios vivo y liberador. Por esto en otro lugar de mi libro, al referirme al mensaje de Jesús y al texto que lo encierra, digo: "el inensaje esłá históricamente ligado al texlo. Este funciona como clave para descifrar el mensaje. Sin el testimonio del texto perderiamos el acceso histórico al mensaje y a aquel Jesús que vivió entre nosotros. Por esto la fe, que se presenta como fuerza histórica, esta ligada a los primeros textos'" (p. 127). Asi pues, no defiendo, como injustamente se hace notar, una concepción predoctrinaria de la revelación.

El mismo texto del cardenal me da nuevamente la razón cuando reconoce que, "es verdad que las formulaciones dogmáticas responden a problemas de un momento histórico determinado y son propuestas con el vocabulario propio de la culıura de aquella época." Entonces ¿qué sentido tiene criticar mi posición si hay concordancia entre mi concepción y lo que expone la carta del cardenal? Está claro que, mientras dure la relación con la cultura comprendida por quienes la viven, las verdades "seguirán siendo verdaderas." Al cambiar la cultura no cambia la verdad, sino las formulaciones culturales apropiadas que deben expresar la misma verdad y el mismo significado dado por la Iglesia, como ya dijimos antes. 
c) El significado dinámico del "depositum fidei"

Estoy de acuerdo y acepıo plenamente los térıninos del n. 10 de la Dei Verbum y el $n .23$ referido a los teólogos. El papa Juan Pablo 11, hablando a los teólogos en Salamanca, explicó el significado de este depósito: "El teólogo no puede limitarse a conservar el tesoro doctrinal heredado del pasado, sino que debe buscar una comprensión de la fe acorde con el pensamiento de nuesiro tiempo. El criterio que debe guiar la reflexión teológica es la búsqueda de una comprensión renovada del mensaje cristiano, en la diaiéctica de la renovación, en la continuidad y viceversa (SEDOC 15,1983,653 o L'Oss. rom., ed. port. 7/11/1983; cf. también el discurso a los obispos de Bélgica, 10/9/1982).

Comentando la Dei Verbum en el tema que nos conscierne, un gran teólogo, Henri de Lubac, hoy cardenal, y con problemas en otro tiempo con el ex Santo Oficio, escribió: "la tradición no debe entenderse exclusivamente como un depósito acumulado del pasado, conservado fuera del tiempo, comno acto contemplativo de la verdad revelada; esto nos colocaria en una falsa eternidad mientras que los grandes contemplativos de la tradición cristiana, que fueron a menudo grandes hombres de acción, nos dan un ejemplo muy diferente. La tradicion debe confrontarse constantemente (por asi decir) con los acontecimientos del mundo, con las distintas culturas de los pueblos, donde la Iglesia se encarna en el curso de la historia. Por eso reflexionar sobre Cristo o, como suele decirse, hacer teología no consiste sólo en organizar las verdades, reducirlas a un sistema o llegar a nuevas conclusiones partiendo de premisas reveladas; es mucho más, es verificar la fuerza explicativa de las verdades de la fe en el interior del contex1o inestimable del mundo. Es intentar comprender este mundo, es decir, comprender al hombre, su naturaleza, su destino, su historia es las más variadas vicisitudes a la luz de estas mismas verdades" (La révélation divine, op. cit., 100).

Por ello no basta con "conservar fielmente el depósito en su pureza" como dice el tex1o, es preciso abrirse al mundo para dar frutos y convertirse en sal de la tierra. La sal realiza su naturaleza de sal si en verdad da gusto a los alimentos distintos de ella.

Lo que se me atribuye en la p. 130 sobre "el proceso único y dialéctico de la historia" no tiene nada que ver con el sentido de la dialéctica que he expuesto ahi, a saber, la coexistencia dentro del catolicismo del aspecto de encarnación de la trascendencia. Llamo la atención al hecho de que en el texio antes citado, el Papa ha usado la palabra dialéctica sin cargarla de preconceptos y sin suscitar fantasmas de miedo. De la misma forma que en las páginas citadas 73/74 no se dice ni siquiera una palabra sobre el "primado de la praxis." En aquellas páginas se critica una concepción de la revelación que la reduce a las doctrinas reveladas y esconde lo principal, a saber, el Dios revelador, como expuse arriba y como subrayaron los concilios.

\section{Los eventuales abusos del poder sagrado en la Iglesia y el ideal evangélico}

He aquí lo que afirma el tercer punto de la carta de cardenal Ratzinger. 
"Otra grave patologia" de la que en su opinión tendría que liberarse la Iglesia romana sería el ejercicio hegemónico del poder sagrado, que, además de convertirla en una sociedad asimétrica, habria sido deformado en si mismo.

Dado como probado que el eje organizador de una socicdad coincide con su forma específica de producción, y aplicando este principio a la Iglesia, Ud. afirma que se ha dado un proceso de expropiación de los medios de producción religiosa por parte del clero en perjuicio del pueblo crisliano, el cual se ha visto asi expropiado de su capacidad de decidir, enseñar, elc. (cf. pp. 192 ss; 215 ss; 238 ss).

Una vez desplazado de su lugar el poder sagrado ha sido también gravemente deformado, pues cayó en los mismos defectos del poder profano: "el ejercicio del poder en la Iglesia siguió los criterios del poder pagano en términos de dominación, centralización, marginación, triun falismo; subterlugio humano bajo capa sagrada"' ( $\mathrm{p} 98$; $c$ r. tánbién 87, $91-94$ etc.).

Para remediar estos inconvenientes Ud. propone un modelo nuevo de Iglesia, en que el poder se conciba sin privilegios teológicos, como puro servicio articulado según las necesidades del pueblo, de la comunidad. Se trata de "hacer una Iglesia viva, con servicios flexibles, funcionales, sin privilegios teológicos" (p. 207; cf. p. 98 ss., elc).

Semejante postura despierta serias reservas doctrinales y pastorales.

En relación con esta última parte -el ejercicio del poder sagrado en la Iglesia - entran en discusión particularmente los capitulos V, "El poder y la institución en la lglesia ipueden convertirse?;" el VIIIs "Caracteristicas de la Iglesia en una sociedad clasista;" el IX, "¿Está justificada la distinción entre Iglesia docente y discente?" y los últimos sobre la Iglesia y el Espíritu Santo.

a) La siruación de la lglesia en Brasil y los desafios a la Iglesia-instilución.

Para entender los desafíos es preciso situarlos en las condiciones eclesiales del Brasil en el interior de los cuales elaboro mis reflexiones. Como dije al principio, estamos atravesando una grave crisis institucional por la falta sentida y dolorosa de sacerdotes. Las estadísticas dan 1.3 sacerdoles por cada 10 mil fieles. El pueblo es religioso reclama con insistencia la presencia de la Iglesia.

Esta situación de escasez de sacerdotes permite la penetración de centenares de denominaciones cristianas, sectas, religiones orientales y la difusión cada vez más acentada de religiones afro-brasileñas. Dicen los experıos que de continuar esta situación dentro de 60 años el catolicismo no será la religión dominante a nivel popular. Es un terrible desafio pastoral que una teologia atenta no puede soslayar de su agenda de reflexión. La estructura tradicional de la Iglesia, excesivamente construida sobre la figura del sacerdote ordenado y célibe, crea cada vez más obstáculos en el esluerzo de superar el inmovilismo institucional. En cambio la Iglesia del Brasil ha encontrado una posible solución: los miles de comunidades de base. Aquí el pueblo lee la Palabra, celebra, organiza la caridad, permitiendo así el nacimiento de nuevos ministerios laicos. Co- 
mo ya dijimos, los obispos apoyan a las comunidades eclesiales y èslas acogen a los obispos en admirable sintonia. Aqui se puede ver cómo la le vivida en comunidad permile el surgir de nuesiras estrucluras funcionales sin romper con la tradición y los elementos clásicos de la estructura de la Iglesia universal.

En este contexto y estadio de búsqueda y de ampliación de las posibilidades eclesiológicas es donde se sitúa mi Irabajo. Cilo una frase de Rahner: "frente a la nueva situación, la lglesia debe ir con coraje hacia lo nuevo y aún no experimentado hasta el limilc úlıimo, hasta el punio en donde una doctrina y una conciencia cristiana, clara e indiscutiblementc, no pueden ir más lejos.

En la vida de la práctica de la Iglesia, hoy dia, el único "tuciorismo" (certeza) permitido es el "tuciorismo" de la audacia... Lo seguro hoy no es ya e. pasado sino el futuro" (Handbuch der Pasioral Theologie II/I, Freiburg, 1966, 275-276).

Evidentemente no he llevado mis propuestas hasta los extremos, pero las novedades que sugiero se sitúan en el ámbilo de esta urgencia pastoral. En América Latina y en Brasil tenemos que hacer una teologia de urgencia. De lo contrario perderemos el tren. Nos suplantará la enorme vitalidad religiosa del pueblo, secuestrada por otros grupos ajenos a la lglesia católica, religiosidad enraizada profundamente en el ánimo de la gente. Hay que tener presente también que en el $\mathbf{2 0 0 0}$ más de la mitad de los católicos del mundo serán latinoamericanos. Con esta preocupacion el cardenal A. Lorscheider notificaba a los padres sinodales en 1974 (Panorama de la Iglesia universal a partir de 1976): "examinese la estructura actual de la Iglesia y véase hasta qué punto podria y debería ser diferente en nuestros dias" (Citado en: Iglesia: carisma y poder, p. 99).

Con la intención de crear un espacio mayor dentro de la Iglesia para las modificaciones necesarias y exigidas por los desafios pastorales, analizo a continuación la forma y el ejercicio del poder en la historia de la Iglesia. No tengo intención alguna de difamar, sino que deseo ver a la Iglesia más abierıa, más católica, para que pueda ser la Iglesia de la mayoria del pueblo brasileño.

b) La legirimidad de las categorias socio-analiticas aplicadas a la instirución de la Iglesia

Antes de conlestar a las cuestiones más concretas, es importante garantizar la legitimidad de la aplicación de categorias históricas y socio-religiosas en el análisis de la Iglesia-institucional. La Iglesia tambièn es una sociedad con organos jerárquicos, una asamblea visible (LG 8), por tanlo una realidad hisı́rica y no es sólo esto, es también el sacramento de la salvación universal; ambos elementos forman "una sola realidad compleja en la que coexisten (coalescit) el elemento divino y el humano" (LG 8). El elemento humano, como en el misterio de Jesús, posee una relativa autonomía (verus homo). Por ello se puede discurrir sobre la Iglesia como institución histórica y social bien entendido -en la fe-que esta institución constituye, a los ojos de la fe, la sacramentalidad teológica de la Iglesia. A esta realidad histórico-religioso-social, podemos aplicarle los instrumentos analíticos elaborados por las ciencias sociales y los 
específicos para el campo religioso. Es cierto que esta ciencia liene una tradición reciente, pero no por eso carece de seriedad.

Resulta útil para comprender los condicionamienlos sociales de la Iglesia institucion, las formas de poder y la forma como se ejerce. Reconozco que no se utiliza frecuentemente esta mediación socio-analítico-religiosa en las eclesiologias modernas, ni siquiera en Hans Küng. Soy conscientes de que los teólogos de América latina somos unos innovadores en esie aspecio. Me he suvido de los estudios más serios en este ámbito: Pierre Bourdieu, A economia das trocas simbolicas, S. Paolo, 1974, spec. cl capitulo "Gicnese e estruclura do campo religioso" (pp 27-78); Otto Maduro, Campo religioso y' conflictus sociales, referencia teórica para el análisis de sus interrelaciones en América latina, Caracas, 1978: C.A. de Medina y Pedro A. Ribeiro de Oliveira, Aulorilá e participazione, Siudio sociologico de la Chiesa callolica. Petropolis, 1973. El magisterio reconoce oficialmente la utilización de las ciencias humanas y sociales, respetando la epistemologia propia de la ciencia. (Octogesima adveniens, n. 38 y 40; Juan Pablo II," Discurso en la pontificia universidad de Salamanca," cl. SEDOC, gen/ (ebr, 1983, 652-656).

En este nuevo horizonte epistemológico deben entenderse expresiones técnicas como," capital simbólico, medios de producción religiosa, modo de producción disimétricos de producción religiosa, proceso de expropiación de los medios de producción religiosa" (cf. p.e. 178-179). Considero que tales expresiones no poseen una connotación moral, sino meramente analítica. Sobre ello llamo explícitamente la atención del lector en las pp. 179,216 y siguientes. Además, históricamente la teología siempre se demostró dispuesta a asumir nuevas categorías procedentes de los distintos campos del saber, con tal de que no se alterase la identidad de la fe. Hoy las ciencias sociales son un desafio que debe afrontarse con coraje y prudencia, porque son útiles y permiten comprender mejor la institucionalidad de la Iglesia. Particularmente útiles porque muestran además las relaciones de nuestra influencia que concurren entre Iglesia y sociedad. Hay modos de ejercer el poder en la Iglesia que son el Iributo de su encarnación en el mundo feudal, otros de su presencia enl la sociedad moderna, otros en fin de los estados populares. No lodo se ha instiluido divinamente, ni podría serlo por más que la encarnación sea también no sólo un acontecimiento histórico-salvifico, sino además una presencia de lo divino en lo humano (transparencia).

La carta del cardenal dice que "desde el punto de vista teológico no tiene sentido introducir en la sociedad eclesial los medios de producción como eje vertebrador." Cierto, desde el punto de vista citado, pero no es desde la perspectiva socio-analítica de la que partimos.

La carta se pregunta a renglón seguido: “¿acaso no posee la Iglesia de Cristo una organización original propia, independiente de los medios de produccion?" Que la Iglesia posea una organización propia no le exime de tener medios de producción; la Iglesia, en efecto, en cuanto sociedad visible de hoinbres y mujeres tiene que comer, poseer sus edificios, organiza sus dicasterios, promueve misiones, garantiza el pan y el vino para la celebración 
eucarística. Tiene pues medios de producción de vida y de reproducción de la misma, y hasta instituciones financieras como el Instituto para las Obras de Religión (IOR). Si el Verbo encarnado estaba inmerso en el medio productivo de su tiempo, ¿por que no habia de estarlo la Iglesia? Por lo tanto, este principio no es extraño a la teologia, quizás su formulación nueva, fruto de la sociología religiosa moderna, cause extrañeza a oidos acostumbrados a un sólo lipo de lenguaje.

\section{c) La pérdida progresiva del poder de decisión de los laicos enl la historia} de la Iglesia

Tras estas observaciones iniciales paso a contestar a las cuestiones presenIadas. "El proceso de expropiación de los medios de producción religiosa por el clero en perjuicio del pueblo cristiano, que se ha encontrado despojado de su capacidad de decidir, enseñar, etc." Se trata de un hecho histórico. Basta con conocer un poco la historia de las instituciones eclesiasticas. Los hechos cantan, poco importa que nos gusten o no. Asi se ha dado efectivamente una pèrdida de presencia del pueblo en los procesos de decisión en el interior de la Iglesia. Tomemos como ejemplo su participación en la elección del obispo en otros tiempos.

San Clemente Romano en su Carta $(44,3)$ afirma que los presbiteros fueron instituidos por los apóstoles y por hombres insignes "con la aprobación de toda la comunidad." La Traditio Apostolica de Hipólito (215) afirma: Episcopus ordinatur electus ab omni populo (n 2). Las Constituciones apos/6licas prescriben que "sea consagrado obispo una persona completamente irreprensible y sea elegida por todo el pueblo" (VI11, 4,2: Funk 1, 473). Para Cipriano, una elección sin el sufragium populis es ilegitima (Epis. 67,5; CSEL $3,2,7,39)$. El Concilio de Reims en el 1049, presidido por León IX, esıablece en el canon 1: "que nadie sea promovido al gobierno eclesiástico sin ser elegido por el clero y el pueblo."

A causa de la arbitrariedad de los príncipes que praclicaban la simonia, los laicos fueron apartados progresivamente de la elección de los obispos. Apenas si se les pedirá el consentimiento. Así en 1140 el decreto de Graciano al tratar este asunto dice en forma inicial: "la elección perlenece al clero, el consentimiento, al pueblo" (Dist. 62 y 63). 800 años después, el canon 329/2 del código de 1917 afirma: "el pontifice romano libremente nombra a los obispos." En 1983, el nuevo código de derecho canónico, dispone en el canon 317, "el sumo pontifice nombra a los obispos libremente o confirma a los legítimamente elegidos." Sólo en el proceso previo de información, y "si se considera oportuno," permite consultar "individualmente y en secreto" también a los laicos eminentes en sabiduria" (c. 377/3).

Como se deduce de estos hechos, los laicos han perdido el poder eclesial, el poder de contribuir en las decisiones para la elección de sus propios pasiores. En ciertas épocas se ha perdido el recuerdo de esta despotenciación de los laicos. Podemos asi leer frases como estas de Pio X en la enciclica Vehementer (del 11/02/1911): "solamente el colegio de los pastores tiene el derecho y la autoridad de dirigir y gobernar. La masa no tiene derecho alguno si no es el de 
dejarse gobernar como grey obediente que sigue a su paslor" (cl. Iglesia: carisma y poler, p. 218 ).

Ahora bien, esta teologia ya no aparece en el Valicano II, como se ve en la Lumen Gentium (33 y 36), donde tambièn los laicos participan, a su manera, en los ires dones de Jesucrisı y de la Iglesia: celebrar, enseñar y gobernar.

\section{d) Los abusos del poder sagrado i' la idefectibilitad de la lghlesia}

Afirma lambien la carla del cal clenal Ratringer:

Dado pero no aprobado pue el ejercicio del poder en la historia de la lglesia pudo ser tan negalivo, icon que objeto se acemúa un panorama lau deprimente? ¿Como deberia ser el cjercicio del noder en el nuevo modelo de Iglesia? ¿Quién Iendria que ejercer Ial poder? ¿Qué ha de entenderse por servicios flexibles, funcionales, sin privilegios teológicos? La doctrina tradicional de la Iglesia en este punıo, claramente confirmada lambién por el Concilio Valicano II, supone entre utras cosas dos verdades fundamentales: a) la constitución de la lglesia es jerárquica por institución divina; b) existe en la Iglesia un misterio jerárquico ligado csencial y exclusivamente al sacramento del ordell.

Queda todavia otro problema, del ejercicio del poder en la Iglesia. Acjui se cita una frase que es mia, pero que no representa la vision mas complcja y completa de mi postura: "el ejercicio del poder en la lglesia ha seguido los criterios del poder pagano en términos de dominación, centralismo, marginación triunfalismo, hybris humana bajo la forma cle cobertura sacramental" (p. 98 , cf. también 87, 91-94, elc.).

Pienso que la forma de ejercer el poder en la Iglesia es un probleına objecivo, lanto en el pasado como en el presente. El ejemplo de Jesús es orientador: lue siervo doliente y despojado de todo honor y aparato exicrno. Las autoridades de su liempo lo crucificaron; èl no ulilizó el poder-dominación para hacer valer su mensaje y menos para imponerlo a los deınás; mucho menos aún para defenderse y sobrevivir (cf. pp. 103-105). Todavia hoy sufrimos el mal ejemplo de prelados auloritarios; con su excesiva mania de mandar, hacen sufrir de forma excesiva a sus fïeles. Esto forma parte de la situación deciadente que invade tambièn a la Iglesia. El hecho no constituye ningún motivo para despreciar la Iglesia y el ministerio pastoral, sino para cjercitar la profecia en su interior y saber sufrir por ella. Debe valer siempre lo que coseno Pabla: "no tenemos poder contra la verdad sino únicamente por la verdad" (2 Cor. 13,8). Cualquier pais en su historia y en la actualidad, podria presentar dolorosos ejemplos de lideres comunitarios autoritarios, párrocos dominantes y obispos centralistas. En mi texto y en la perspectiva que presenti antes, intento hacer un "pequeño balance" (p. 97) subec el cillmillo hivbirico de la lẹksiainstitución-poder, que sucedió a la lglesia de los maŕtires; es decir, después del giro constantiniano cuando se convirtió, conso religion oficial, en una fuer/a histórica. Mi perspectiva es critica: conocido el ejemplo de Jesús, los valores evangélicos y el ejemplo de los apóstoles podia esperarse un ejercicio del poder distinto, más servicial, con menos aparato y más generador de fraternidad. En realidad, el ejercicio del poder en la lglesia siguió en muchisimas ocasiones el 
curso común e incluso pagano del poder.

El iexto del cardenal Ratzinger ine hace esıa pregunta: "dado aunque no concedido que el ejercicio del poder en la hisıoria de la Iglesia puede haber sido tan negativo ¿con qué objelivo sc acemtúa un panorama tan deprimente?"'

Unilizo las palabras del libro ju/gado: "si reconocemos el pasado ran poco vivificante cle la Iglesia-instiución, en relación con el ejercicio del poder, esto

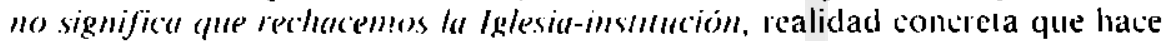

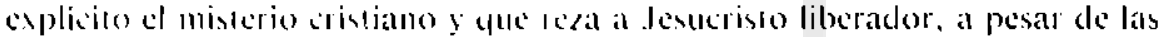
comtradicciones internas clel sistema. Todo cristiano debe asumir este pasado que no se puede ignorar ni resaliar... porque es muestro pasado, porque somos miembros del pucblo de Dios en cuyo interior se sitúa la Iglesia jerárquica" ( $p$. 100). Por lo lanto, esic pasado no es sólo de los obispos, sino también nuestro, de los cristianos, presbiteros y laicos. Complcıo luego mi pensamien10, "sólo un amor concrelo y cvangélico, y por esı mismo, crílico y libre, puede acepıar a la lglesia con sus limiıciones y errores; porque sólo arnándola nos convertimos a nosotros mismos y comienza a desvelarse la lascinante belleza de la esposa de Cristo y madre de codos los hombres" (p. 101).

Si hubiera querido dilannar a la Iglesia por el simple gusto de difamarla hubiera tenido mil formas diversas de hacerlo. Creo que debemos aceptar, con humildad y autocrítica, que se han dado eleclivamente escándalos en el ejercicio del poder de la Iglesia, incluso en las más altas esferas como en varios casos de papas a lo largo de la historia.

Recordaré apenas un par de casos: podría cilarlos, pero no lo he hecho simplemente para no escandalizar a los fieles. No lo inventaria, sería simplemente narración de lo que se encuentra en los manuales de hisioria. Tenemos algunos del creyente D. Rops, La Iglesia de los tiempos bárbaros, (Historia de la Iglesia de Cristo, II, Porto 1960). En el capitulo "San Pedro y los tiranos de Roma" (p. 617 y 624) nos dice: "en ninguna olra época se mostró el papado tan débil y án clesigual en su misión... descariamos echar sobre el especláculo de este desorden el manio de los hijos de Noé" (p. 617). Lo que se cuenta del Papa Juan XII (955-964), consagrado a los 18 años y de como ejerció el ponlificado, es peor que el ejercicio pagano del poder, según Rops: "participaba en lodas las intrigats...; respecto a il se narran - quizas conl cierta exageracionpero con imnegable londo de verdad- las peores historias de bancjuetes orgiáslicos en los que se cuenta que los convidados daban brindis a Lucifer" (p. 618). Benedicio IX (1033-1045) luć consagrado Papa a los 12 anos. "ya lleno de vicios y con lantos escándalos que el pucblo romano acabó por indignarse

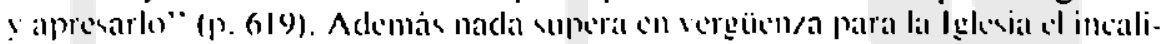
ficable abuso de poder que el Papa Esleban VI (896-897) practicó con el cadaver del Papa Formoso (891-896). "Sacó el cadáver del anciano Papa de la lumba, lo senıó en una silla y fuć juzgado por una asamblea sinodal presidida por cl Papa Esteban VI que lo odiaba. Con él desenterró lodo su pasado; revocó todas sus aventuras y enredos y denunció todas sus faltas contra el derecho canónico. Un clérigo, aterrado, contestaba en lugar del difunto y confesaba sus "crímenes." Siguió una ceremonia abominable en la que se privó al difunto de 
su dignidad, se le despojó de las vestiduras pontificales, pegadas ya a la carne putrefacta, le quitaron el cilicio que llevaba, le cortaron los dedos de la mano derecha - aquellas manos indignas que habian bendecido al pueblo. Y, para concluir, se entregó el cadáver al pueblo que to tiró al rio" (p. 548-549).

Estos y parecidos crimenes, en papas mundanos que se sucedieron en el periodo renacentista, no están a lavor del ejercicio del poder según los dictámenes evangélicos de un mínimo de humanidad y sentido común. Hay panoramas deprimentes en la historia de los papas, obispos, jerarquia y también laicos. La carta del cardenal Ratzinger me critica por haber apenas insinuado hechos de prepolencia e hybris humana sin conocerlos; si lo hubiera deseado podria haberlo hecho dentro de la objetividad de la historia eclesiástica. La voluntad de auto-alirmación de la Iglesia y de la jerarquia no debe sofocar el senlido de auto-crítica, de conversión y de humilde reconocimiento de los errores y pecados hisı́óricos cometidos por quienes deberian respetarnos la figura del siervo doliente, el humilde y el pobre Jesús de Nazaret.

Mi exposición en el libro Iglesia: carisma y poder no se entretiene morbosamente en esta critica. Va orientada en la perspectiva pastoral y evangélica de conversión y de la necesaria apertura de todos para que sea posible una mayor floración de los bienes del reino, de la participación y comunión entre todos. Dedico toda una larga sección a exponer "el sentido evangélico de la autoridad" (p. 101-105), vivido en la lglesia que nace de la fe del pueblo sencillo, concretizada en las comunidades cristianas de base. Aqui hay pastores excelentes, sacerdotes inmersos entre los pobres, religiosos y religiosas que han unido su destino al destino de los últimos de la tierra, los hermanos menores del Senor ( $c f$. Mt. 25,40). Aqui señalo cómo se vive un poder-servicio, donde los portadores del poder consagrado en la Iglesia lo ejercen como un verdadero servicio, dando posibilidad de participación a los demás; en vez de concentrar todo en las propias manos, refuerzan el poder del pueblo cristiano para que participe y sea miembro activo de la comunidad. Digo más: "el papado, el episcopado, el presbiterado no perderán su función; ganarán olras, aun más puras y cercanas al ideal evangélico de confirmar a los hermanos en la fe..." (p. 108). Concluyo reconociendo que "los últimos papas de la Iglesia, se sitúan fundamentalmente en el interior de estos últimos ideales"' (p. 108).

Es aqui donde quiero llegar cuando digo que es importante: "hacer una Iglesia viva, con servicios flexibles, funcionales, sin privilegios leológicos." Existen los ministerios oficiales que nos vienen del sacramento del orden; pero existen también, de hecho, los ministerios desempeñados por los laicos, en las pluriformes experiencias comunitarias, como preparar a los niños para la primera comunión, la liturgia y las celebraciones, visitar ancianos y enfermos, administrar el bautismo y asistir al matrimonio, animar los grupos biblicos, coordinar los centros para la defensa de los derechos humanos, etc.

Todas estas funciones (carismas) que el Espiritu despierta en la comunidad, muestran la vitalidad, la flexibilidad de los servicios, la parlicipación de todos, sin privilegios teológicos de algunos en detrimento del valor también teológico de los demás. 
En ninguna parte de mi libro niego la constitución jerárquica de la Iglesia, de institución divina. Pero la jerarquia, en el transcurso de la historia, asumió el poder que ahora en la Iglesia latina los laicos tendrán que emplearse a rondo si quieren recuperar su sitio. La formulación del eminente teólogo Salaverri citado en las pp. 215-216, expresa mal la perspectiva querida por Jesús en una comunidad de hermanos (cf. Mt. 23,8), donde todos son hijos del mismo Padre celestial: "en la lglesia existe por deseo de su fundador una discriminación por la que algunas personas tienen que ser llamadas al ejercicio de los poderes esenciales, excluyendo a los otros, según la ley insıaurada por el inismo Cristo." Lo mismo que afirma el Papa Gregorio XVI (1831-1846): "nadie puede ignorar que la Iglesia es una sociedad de desiguales en la que Dios ha destinado a unos para gobernar, a los demás para servir. Estos son los laicos, aquellos los clérigos" (p. 218). Las palabras "discriminación," "exclusión," "desigualdad," "gobernantes," - por un lado-y "servidores" — por otrodificilmente pueden tener un aval en el evangelio. No fue así como obró y hablo Jesucristo. Existe la jerarquia en la Iglesia, pero no como entre los grandes y poderosos señores de este mundo (cf. Lc. 22,25), sino a modo de "hierodulia," es decir, servicio sagrado, sin discriminación ni separaciones; poder, en cambio, para unir la comunidad, animándola para la misión y hacerla una seguidora más fiel del siervo de los siervos, Jesucristo.

\section{e) El laico y la celebración de la cena del Sentor}

Finalmente la carta del cardenal vuelve a una quaestio dispulala que formulé hace años con relación a la práctica de las comunidades eclesiales de base, por falta de sacerdotes, siempre tan queridos y anhelados. Algunas comunidades en ciertas ocasiones, especialmente el Jueves Santo, ritualizan y celebran la cena del Señor, bajo la presidencia del coordinador laico, reconocido por la Iglesia local. Surge entonces la cuestión teológica, iqué valor tiene semejante celebración? ¿Es tan sólo una paraliturgia? Aqui lanzo una hipólesis que formulo así (Eclesiogenesis, Petrópolis 1977,79): el coordinador laico, dentro del suplet ecclesia (oeconomia), actuaria como minis(ro ex(raordinario, sin que por ello se invalidara la necesidad de la ordenación sacerdotal, ni se constituya un nuevo ministro presbiteral en lugar del ya existente en la Iglesia (op. cit. 80-81). Mantengo que yo nunca he afirmado, como supone la carla del cardenal, que no sea "necesaria la ordenación sacerdotal para la validez de la Santa Misa." En mi quaestio dispurata no hablo de la misa, sino de cena del Señor, dado que la misa es una realidad sacramental, teológicamente bien clefínida y oficial para toda la Iglesia.

En mis "Aclaraciones sobre algunos temas teológicos" (Grande Sinal, junio de 1982, 368-369) o en Sal Terrae, mayo de 1982, 400-401) he intentado clarificar mi postura. He visto que ha causado escrúpulos manifestados en la carta de Mons. J. Hamer del 25 de junio de 1982, y ahora en la del cardenal Ratzinger.

En realidad mis formulaciones son claras. Las transcribo y vuelvo a clarificarlas. "La Iglesia enseña que toda la comunidad eclesial es sujeto activo en la celebración eucarística. Esta tesis no contradice la afirmación solemne de la misma Iglesia, según la cual sólo el sacerdote válidamente ordenado o el obis- 
po tiene poder de consagrar (DS $1739 \mathrm{~s} ; 1752 ; 1771$ ). Esto significa: sólo el sacerdote oficial, dentro del Ordo de la lglesia, puede, como ministro ordinario, propunciar eficazmente las palabras en cuya virtud se hace presente la víctima elicaristica, el Cuerpo y la Sangre de Jesús" (Grande Sinal, op. cil. 369; Sal Terrae. 401).

Repito finalmente a modo de conclusión: "de todas maneras debemos reconocer que no existe celebración eucarística propiamente dicha, en sentido canónico, como la entiende la Iglesia católica, cuando el celebrante no es ministro ordinario, ordenaclo válidamente con el sacramento del orden" (ibid.).

Llamo la atención sobre las exclusiones negativas, que en buena lógica menor, no permiten alternativas: "sólo" (dos veces) y "no existe celebración..." Añado "como ministro ordinario" para reforzar lodavía más la afirmación precedente: "sólo el sacerdote oficial." Aunque hubiera omilido el "como ministro ordinario" no cambiaria en nada el sentido. Como me solicitó esta Congregación en la carla del 26.6.1982: que se omita de una vez. por todas para mayor claridad.

La segunda añadidura "en el sentido canónico como lo entiende la Iglesia católica" quiere una vez más subrayar la doctrina oficial; no quiere sustraerle nada, como aparece ya claro en la misma formulación, si se lee sin escrúpulos y sin excesiva desconfianza. En este sentido afirma el Concilio IV de Letrán: Sacerdos, qui "rite" fueril ordinatus (DS 802; y DS 794). El canon significa: según la norma y determinación de la lglesia. Si eliminamos este añadido no se modifica en nada el sentido de toda la frase. Que se elimine, pues.

Finalmente estoy convencido del carácler fragmeniario de mis "ensayos de eclesiologia militante;" no tienen la consistencia de un tratado sistemático de eclesiologia, que deseo elaborar algún día.

Después de haber justificado el derecho a la profecia en la Iglesia y su ejercicio por parte de santos y teólogos con cualidades mucho mayores que las mias, considero que no he sido más virulento e intolerante que un Origenes, san Bernardo, Pedro Damiani y san Antonio de Lisboa.

Le expreso mi convicción de que "la Iglesia de Cristo debe edificarse en la pureza de la fe." Pienso al mismo tiempo que el cristiano no sólo posee el derecho a recibir la docırina pura, sino rambièn a recibirla en una codificación actual que le permita comprenderla. Esta debe de "acomodar en lo posible el Evangelio a la capacidad de Iodos...," tiene que ser "ley de loda evangelización," como recomienda el Valicano Il (Gaudium es Spes, n. 44/340). Por desgracia no encuentro en la carta del cardenal indicio alguno en esta dirección, ni mucha comprensión para quienes, como yo, con los riesgos propios de esle empeño, asumen esta recomendación. El querer librarse "de los enemigos del pasado y sobre lodo de los acluales" no puede reemplazar a esta misión ni es tampoco la mejor manera de llevarla a término.

$\mathrm{Ni}$ en el libro en cuestión ni en cualquier otro propongo "un cierto socialismo utopico;" menos aún "identificado con el Evangelio" como se me reprocha. Quiero expresar claramente que no puedo aceptar esta sospecha injustificada, como si incurriese en un primitivismo teológico desprovisıo de to- 
da vigilancia epistemológica.

\section{A la verdad y a Dios la última palabra}

Al concluir mi respuesta deseo manifestar que reconozco la legitimidad de la instancia doctrinal de la Iglesia en la promoción y custodia del mensaje revelado por Dios; instancia que ha realizado, como era su deber, el análisis de mi libro. A mi me ha cocado el esfuerzo de disipar dudas, corregir posibles errores y hacer que tome conciencia de los desafios hisıóricos que atraviesa nuestra Iglesia, desafios que provocan la comprensión de la le. He procurado realizar esta lectura dentro del camino de nuestra Iglesia. Si lo he hecho con provecho para la comunidad eclesial, si me he quedado corto para las exigencias de la fe y de la historia, corresponde a quien corresponda y a Dios. Me considero un siervo inútil que ha procurado hacer lo que debia (cf. Lc. 17,10) o creia que debia hacerlo.

En la casa del Padre hay muchas mansiones (Jn. 14,2). Esla casa se encuentra en la tierra y en el cielo. Tambièn en la teologia hay muchos caminos que llevan al encuentro con el mismo Dios y muchas moradas para el lenguaje de la fe. Creo que mis reflexiones eclesiológicas, incluso las más audaces a los grandes acontecimientos que detectamos, se situan dentro del pluralismo teológico tan valorado por el Vaticano Il (UR, n.4/771; GS. n. 44/340).

De una cosa estoy seguro: prefiero caminar con la lglesia, que ir solo con mi teologia; la Iglesia permanece, la teologia pasa; la lglesia es una realidad de fe que yo asumo, la teologia es un producto de la razón que discuto; aquélla es madre con sus arrugas y manchas, esıa es sierva, a pesar de su débil luz y su claridad lunar.

En el intento de servir teológicamente a la lglesia he tenido la audacia de pensar nuestros problemas vitales y proclamarlos en voz alıa. Soy consciente de lo que afirmaba san Agustin, y que he colocado en el frontispicio de mi libro, Iglesia: carisma y poder: "caminamos por vias tormentosas por las que nos veiamos obligados a andar con muchas fatigas y sulrimientos impuestos a los hijos de Adán." Estas fatigas y sufrimientos no son meláforas, sino rcalidades cotidianas. Por ellas he entrado en comunión con tantos hermanos y hermanas que sufren y se fatigan mucho inás que yo bajo el peso del dolor de la vida.

Finalmente me permito testilicar y declarar que amo y continuaré amando la Iglesia, comunidad viva de los discipulos de Jesús en la fucrza cle su Espíritu, más que la tranquila comunidad y el curso sereno de mi camino personal de teologo de periferia, menor, v, por desgracia, pecador.

Fray Leonardo Borr, O.F.M. hermano, leólogo menor y pecador.

Petrópolis, fiesta de santa Rosa de Lima, 24 de agosto de 1984. 